${ }_{551.353}$ W. 1984 e

\title{
The Effects of Muddy Creek on the Biology of the Lower
} Sun River

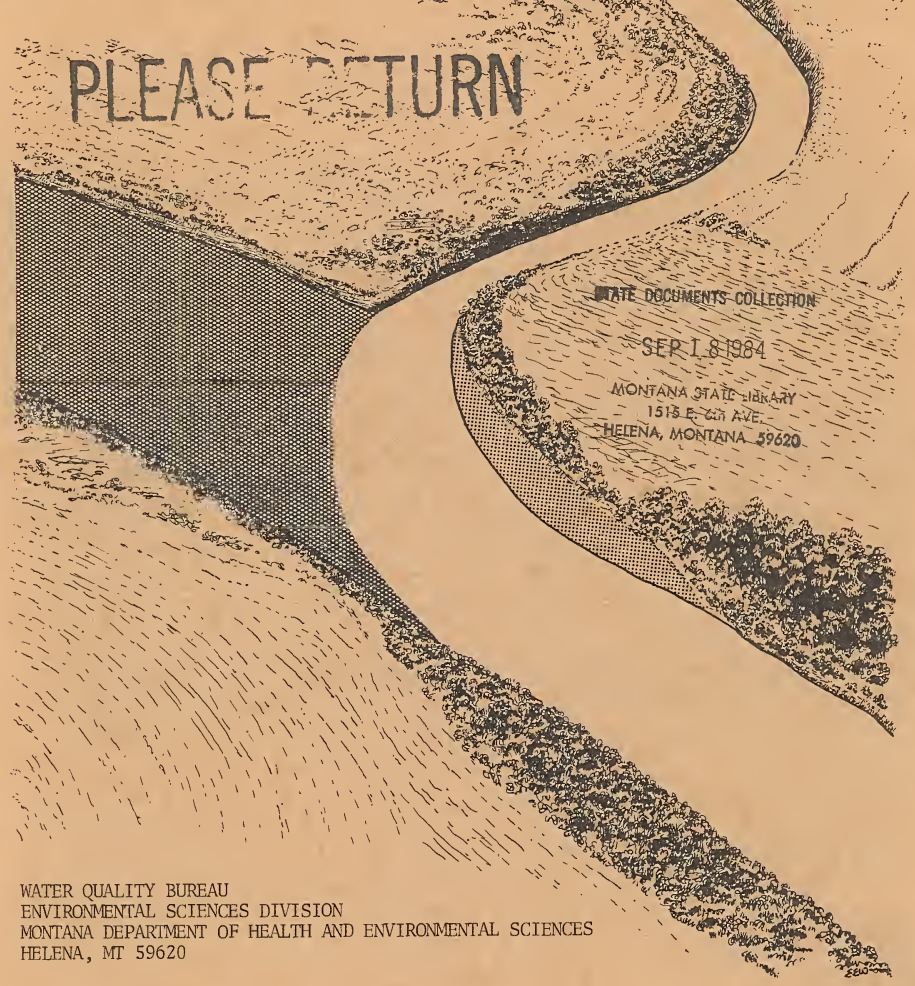


SEP 261990

MAY 15199

MONTANA STATE LIBRARY S 551.353 W3emc 1984 c. 1 Ingman

MAR 2 - 1994.

30864000480452 
THE EFFECTS OF MUDDY CREEK ON THE BIOLOGY OF THE LOWER SUN RIVER

Prepared for

The Muddy Creek Special Water Quality Project and the

Cascade and Teton County Conservation Districts

by

Gary L. Ingman, Erich E. Weber and Loren L. Bahls

- Water Quality Bureau

Montana Department of Health and Environmental Sciences

Cogswell Building

He]ena, Montana 59620

January 1984 


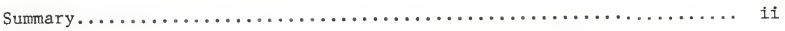

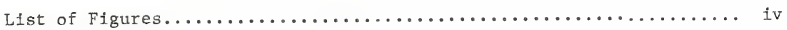

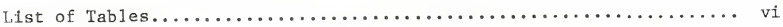

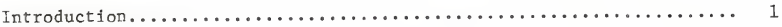

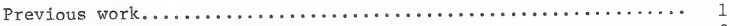

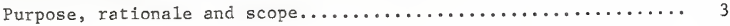

Water Quality Stations.............................. 5

Water Quality Variables............................. 7

Physical variables................................ 7

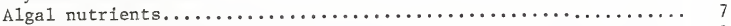

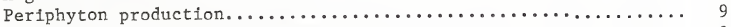

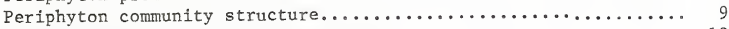

Macroinvertebrate community structure................... 10

Methods.......................................... 11

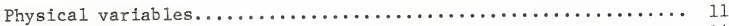

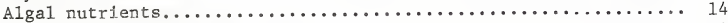

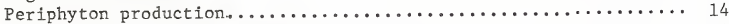

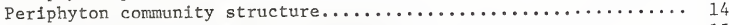

Macroinvertebrate commity structure.................. 15

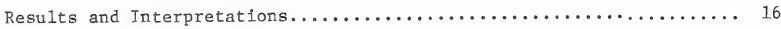

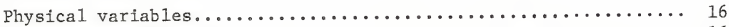

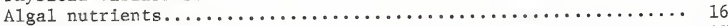

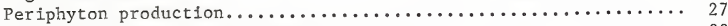

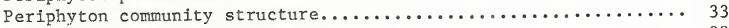

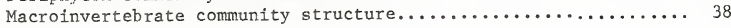

Conclusions...................................... 47

Literature Cited................................. 48

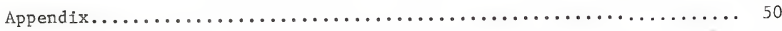


SUMMARY

Muddy Creek is Montana's worst water quality problem. Every year Muddy Creek dumps more than 200,000 tons of sediment and nutrients into the Sun and Missouri rivers west of Great Falls, Montana. The extremely high sediment and nutrient production of Muddy Creek is attributed to accelerated channel erosion caused by hydraulic overloading from unused irrigation water and return flows from the Greenfields Irrigation District.

In September and October of 1980 the Water Quality Bureau, Montana Department of llealth and Environmental Sciences (D.H.E.S.), conducted a comprehensive assessment of the impacts of Muddy Creek silt and nutrients on water quality and aquatic life in the Sun River. The study was designed to (1) determine the nature and severity of impacts on Sun River biology, (2) determine the downstream extent of biological impairment in the Sun River, and (3) establish Muddy Creek as the cause of impairment.

Samples were collected at one station above and three stations below Muddy Creek over a five-week period. Measurements were made of 22 water quality and biological variables in five areas: suspended solids and water clarity, concentrations of algal nutrients, and periphyton (algae) production, periphyton community structure and macroinvertebrate (insect) comminity structure, all. on artifjcial substrates. Standard methods and procedures sanctioned by the U.S. Environmental Protection Agency (F.P.A.) were used throughout the study.

Concentrations of sediment and nutrients in the sun River below Muddy Creek were two to nine times higher than they were above the confluence, and water clarity below was less than a quarter of what it was above Muddy Creek. The attenuation of light by particles of sediment practically curtailed the growth of algae on the bottom of the Sun River for a short distance below its confluence with Muddy Creek. As current velocity slowed, most of the sediment settled and the water cleared at the station farthest downstream, 11.7 miles below Muddy Creek. Here algae production recovered and surpassed that measured at the control station 2.1 miles above the confluence of the Sun River and Muddy Creek, presumably because of nutrient enrichment from Muddy Creek. Nutrient loving blue-green algae were much more common helow Muddy Creek than they were above.

The Muddy Creek sediment plume initially reduced the number of fish food (macroinvertebrate) organisms colonizing artificial substrates in the Sun River by almost 85 percent. Like the algae, the macroinvertebrates also recovered, and at the station farthest downstream numbers surpassed those recorded upstream from Muddy Creek. However, suitable natural substrates for both algae and invertebrates may be limited in the lower sun River.

Measures of diatom and macroinvertebrate diversity in the Sun River proved to be unreliable as indicators of the biological impact of the principal pollutants contalned in the Muddy Creek plume, namely sediment and inorganic nutrients. Computed for both diatoms and macroinvertebrates, Shannon's diversity index (d) and equitability (e) indicated that the cleanest, least polluted water was to be found in the Sun River at the station just below its confluence with Muddy Creek. These findings point 
out the danger in relying on biological diversity alone as a measure of water quality.

Based on the findings of this study, the Sun River is not likely to support a good fishery for the first 2.0 miles below Muddy Creek. During the peak of the irrigation season when the sediment contribution of Muddy Creek is much larger, conditions for aquatic life will be worse, at times extending the impact zone al] the way to the Missouri. River at Great Falls. 


\section{LIST OF FIGURES}

$\underline{\text { Page }}$

Figure 1. Jocation of study area and water quality stations $\ldots \ldots \ldots \ldots 2$

Figure 2. Pollutant concentrations and stream discharge in Muddy Creek at Vaughn during Water Year 1980 (U.S.G.S., 1981)

Figure 3 . Periphyton and macroinvertebrate sampling device........ 12

Figure 4. Concentrations of total suspended solids in the Sun

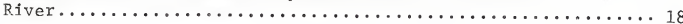

Figure 5. Turbidity in the Sun River....................... 19

Figure 6. Discharge in Muddy Creek and the Sun River............ 20

Figure 7. Concentrations of total soluble inorganic nitrogen in

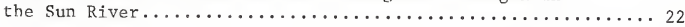

Figure 8. Concentrations of total phosphorus in the Sun River.......23

Figure 9. Mean values and confidence intervals for the rate of chlorophyl] a accrual on artificial substrates in the

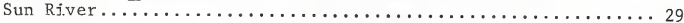

Figure 10. Mean values and confidence intervals for the rate of biomass accrual on artifical substrates in the Sun

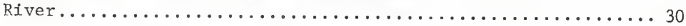

Figure 11. Mean values and confidence intervals for the autotrophic index of periphyton growths on artjficial substrates in the Sun River.......................... 31

Figure 12. Mean vaules and confidence intervals for the chlorophy11. a/pheophytin a ratio of periphyton. growths on artificial substrates in the Sun River......... 32

Figure 13. Total number of diatom taxa found on artificial

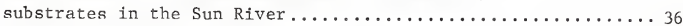

Figure 14. Species diversity (Shannon's index) for diatom associations found on artificial substrates in the

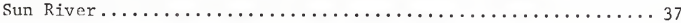

Figure 15. Mean percent relative ahundance of organisms in the major macroinvertebrate orders colonizing basket samplers in the Sun River above and below Muddy Creek.......40 40

Figure 16. Mean values and confidence intervals for numbers of macroinvertebrate organisms colonizing basket samplers in the Sun River........................41 
Figure 17. Mean values and confidence intervals for genus diversity (Shannon's index) of macroinvertebrate communities colonizing basket samplers in the Sun

Figure 18. Mean values and confidence intervals for genus equitability (after Weber, 1973) of macroinvertebrate communities colonizing basket samplers in the Sun River. 


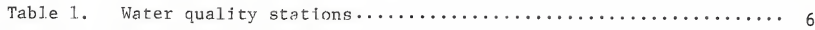

Table 2. Water quality variables $\ldots \ldots \ldots \ldots \ldots \ldots \ldots \ldots \ldots \ldots \ldots \ldots \ldots$

Table 3. Water depth and mean current velocity at individual

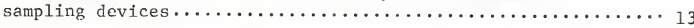

Table 4. Total suspended solids, turbidity and Secchi Disc

transparency in the Sun River...................... 17

Table 5. Concentrations of algal nutrients in the Sun River........ 21

Table 6. Tota] soluble inorganic nitrogen in the Sun River as a

percentage of the recommended maximum instream leve1 $\ldots \ldots \ldots \ldots 25$

Table 7. Total phosphorus in the Sun River as a percentage of

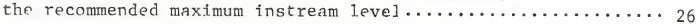

Table 8. Mean values for periphvton production variables in the

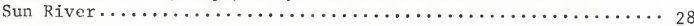

Table 9. Number of genera and abundance of algae in each of the

four alga]. groups found on artifical substrates in the

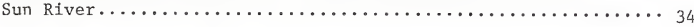

Table 10. Diatom taxa showing large changes in percent relative

abundance downstream from Muddy Creek................. 35

Table 11. Replicate and mean values for variables of

macroinvertebrate community structure in the Sun River....... 39

Table 12. Number of individuals and percent relative abundance

values for ten major macroinvertebrate taxa collected

from basket samplers placed in the lower Sun River.......... 43

Table 13. Values for periphyton production variables measured on

aritifical substrates in the Sun River................ 51

Tabje 14. Significance of differences between stations in mean values for periphyton production variables, using calculated $t$ values and appropriate degrees of freedom....... 55

Table 15. Significance of differences between depths at each station in mean values for periphyton production variables, using calculated $t$ values and appropriate

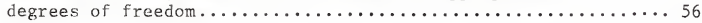

Table 16. Rank and abundance of diatoms and non-diatom algal genera found on artificial. substrates in the Sun River....... 57 
Table 17. Diatom taxa identified from artificial substrates in the Sun River and corresponding percent relative abundance values by station and sampler depth........... 58

Table 3.8. The structure of diatom associations on glass slides

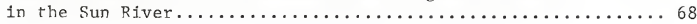

Table 19. Numbers of macroinvertebrate organisms colonizing basket samplers in the lower Sun River................ 69

Table 20. Significance of differences between stations in percent relative abundance values for major macroinvertebrate taxa, using calculated $t$ values and appropriate degrees of freedom..................... 73

Table 2]. Significance of differences between stations in mean values for macrojnvertebrate community structure variables, using calculated $t$ values and appropriate degrees of freednm............................... 74 


\section{INTRODUCTION}

Muddy Creek enters the Sun River near Vaughn in Cascade County, Montana, about $15 \mathrm{miles}$ upstream from Great Falls and the Missouri River (Figure 1). The Muddy Creek drainage includes the large Greenfields Irrigation District. Most of the water used in the District is imported from outside the Muddy Creek basin. At times, irrigation wastewater and return flows carried by Muddy Creek far exceed the stream's hydraulic capacity, resulting in severe streambank erosion. Because of this erosion, Muddy Creek delivers a much larger than natural sediment load to the Sun and Missouri rivers.

Muddy Creek produces more than 200,000 tons of sediment annually. While Muddy Creek comprises only 17 percent of the Sun River drainage area, it accounts for 80 percent of the river's sediment load. Many acres of agricultura 1 land and hundreds of tons of productive soils are lost every year to erosion (Systems Technology, 1.979).

Concentrations of nitrogen and phosphorus exceeding criteria for the prevention of nuisance algae growths have been recorded in Muddy Creek and in the Sun River downstream from Muddy Creek (Ingman et a1., 1979). Downstream water uses impaired by excess silt and nutrients include irrigation, recreation, public water supply and aquatic life. Because of the extent and severity of impairment, Muddy Creek has been ranked as Montana's worst water quality problem (Water Quality Bureau, 1982).

The Muddy Creek Task Force and Special Water Quality Project were organized by the Teton and Cascade county conservation districts in 1979 to correct the problem. Planning and implementation funds and technical and administrative assistance were solfcited. The Task Force identified several water quality data gaps which, if filled, would strengthen the project's chances of being funded. One such gap was the lack of a comprehensive assessment of the impact of Muddy Creek silt and nutrients on aquatic life in the Sun River. This report is intended to help fill that gap.

\section{Previous Work}

The Muddy Creek water quality problem has been the subject of numerous studies. The report by Systems Technology (1979) presents an overview of findings published before 1979 .

Tn addition, Muddy Creek at Vaughn and the Sun River upstream and downstream from Muddy Creek were sampled seasonally for a variety of biological variables in 1.977 and 1978 as part of the state's Biological Monitoring Program (Ingman et al., 1979). Elevated nutrient levels and poor habitat for aquatic life were present in Muddy Creek and at the Sun River station below Muddy Creek. Recause of the lack of adequate control (the upstream Sun River station was about 15 miles above the mouth of Muddy Creek), the problem in the Sun River could not be linked conclusively to silt and nutrients from Muddy Creek.

In a more recent investigatjon, Walther (1982) attempted to determine the relative importance of groundwater and irrigation wastewater drains as 


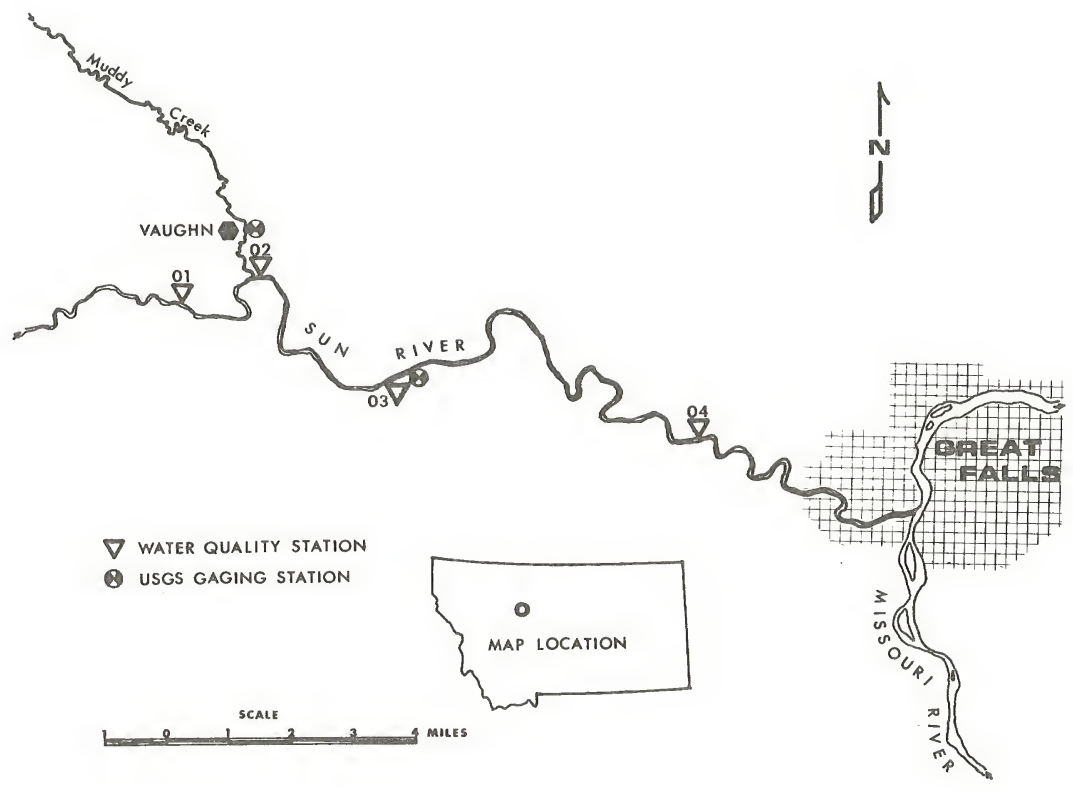

Figure 1. Location of study area and water quality stations. 
sources of nutrients in Muddy Creek. Earlier (1981), Wa1ther reported variable but high concentrations of nitrate in groundwater wells within the Greenfields Irrigation District.

\section{Purpose, Rationale and Scope}

The purpose of this study is to determine the degree and downstream extent of impacts to aquatic life in the Sun River below the mouth of Muddy Creek and to confirm Muddy Creek as the pollution source.

The objective of the 1982 Federal Water Pollution Control Act Amendments (PL 92-500) is to "... restore and maintain the chemical, physical and biological integrity of the Nation's waters." Biological integrity--the relative abundance, diversity and health of aquatic organisms--is a function of water quality. Water pollution often leads to an imbalance in aquatic communities, causing disappearance of beneficial organisms and overabundance of undesirable organisms.

The kinds, numbers and growth rate of periphyton (attached algae) and macroinvertebrates (bottom-dwelling animals) were measured as indicators of water quality. These groups of aquatic plants and animals were studied because they are easy to collect, sensitive to pollution and amenable to statistical analysis. Their members also play key roles in aquatic communities.

Artificial substrates (clean rocks and glass microscope slides) were employed because of anticipated problems in obtafning adequate and comparable biological samples from unstable and variable natura]. substrates. So our results reflect potential growth and community structure, given stable substrates and attachment sites.

Discharge and suspected pollutants (nitrogen, phosphorus, suspended solids and turbidity) were measured for the purpose of inferring cause-effect relationships.

The fleld portion of this study was conducted during september and 0ctober 1980. Worst-case sediment and turbidity conditions prevail in Muddy Creek from May through August of each year. However, it is not practicable to work in the Sun River before September because of the river's usual high water level. Figure 2 shows how discharge and pollutant concentrations in Muddy Creek over the course of water year 1980 compared with discharge and pollutant concentrations during this study. 
Figure 2. Pollutant concentrations and stream discharge in Muddy Creek at

Vaughn during Water Year 1980 (U.S.G.S., 1981).

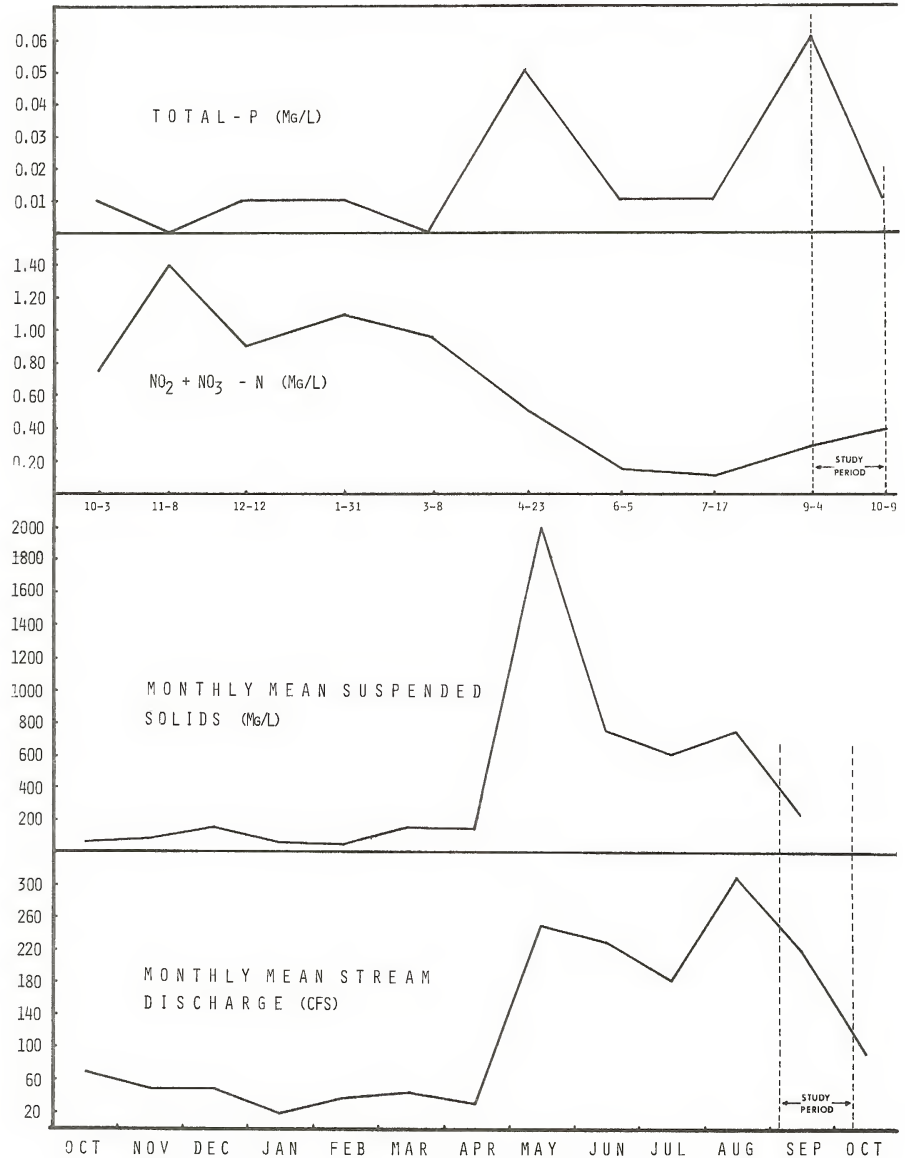


Four water quality stations were located on the Sun River, one upstream and three downstream from the mouth of Muddy Creek (Figure 1). The stations are described in Table 1 . Important considerations in locating the stations were ease of access, proximity to U.S. Geological Survey streamflow gaging stations and physical characteristics of the site. Most importantly, the stations were selected to represent different degrees of Impact from Muddy Creek.

Station 01, the control station, was established 2.1 miles upstream from the mouth of Muddy Creek. Current velocities downstream from this point were much slower than those at the other stations. There are no significant pollution sources between Station 01 and the mouth of Muddy Creek.

Station 02 was located 0.1 mile downstream from Muddy Creek near the left (north) bank and in the direct course of the Muddy Creek discharge. This station was established to reflect the maximum impacts of Muddy Creek during the period of study.

Station 03 was located 3.7 miles downstream from the mouth of Muddy Creek at the U.S. Geological Survey gaging station. This is about the point where the Muddy Creek plume is completely mixed with Sun River water, but mixing may be incomplete under certain flow conditions (Ron Thompson, U.S. Geological Survey, oral communication, 1980). Water quality at this station should reflect the full. dilution capacity of the Sun River and some assimilation of pollutants and downstream recovery.

Station 04 was located 11.7 miles downstream from Muddy Creek and 5.8 miles upstream from the Missouri River. This station was included to determine the amount of downstream recovery and to estimate residual effects in the Missouri River. It was not located closer to the mouth of the Sun River and the City of Great Falls because of access problems, potential disturbance of sampling equipment, and possible effects of urbanization on water quality. 


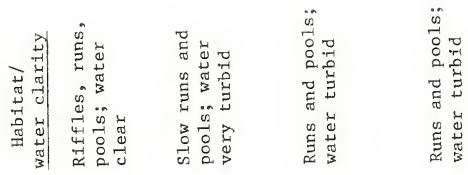
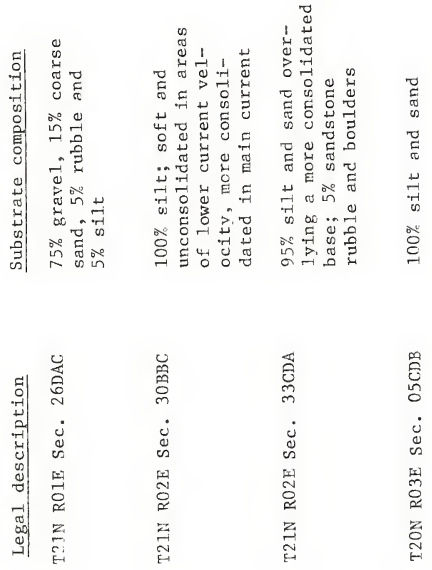


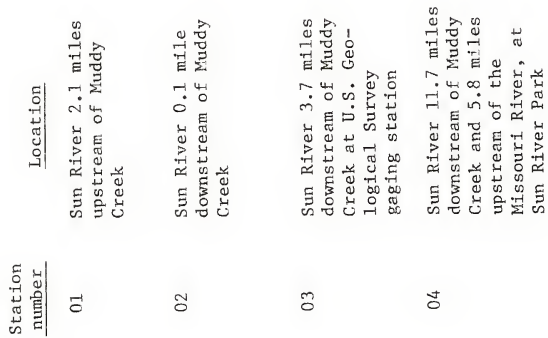

N

ก 
Water quality variables in five categories were chosen for detailed evaluation (Table ?). The significance of these variables is explained briefly in the following sections.

\section{Physical Variables}

Sediment from streambank erosion is the major water quality problem in Muddy Creek, so the measurement of total suspended solj.ds (TSS) is of singular Importance. Muddy Creek sediment is mostly sand, silt and clay. Sediment can damage delicate tissues of aquatic organisms, inundate and smother sessile plants and animals, and destroy aquatic habitat.

One manifestation of sediment is turbidity, which is a measure of water clarity. Excessive turbidity can impair aesthetics, inhibit photosynthesis, jncrease water temperature and reduce dissolved oxygen concentrations. The usual method of measuring turbidity is with a nephelometer and the results are expressed as nephelometric turbidity units (NTUs).

Secchi Disc transparency is also a measure of water clarity. It is simply the depth under the water surface at which a standard disc disappears from view. This approximates the depth to which 5 percent of incident solar radiation penetrates into a body of water (Hutchinson, 1957).

Suspended sediment concentrations in Muddy Creek are directly proportional to stream discharge; peak sediment loads occur during the irrigation season when return flows are hjghest. Streamflow was measured to determine how discharge during the study period compared with discharge over a normal hydrologic cycle. (See Figure 2). Discharge in the Sun River upstream from Muddy Creek determines the amount of djlution water available and the resultant pollutant concentrations and biological effects downstream from Muddy Creek.

Water depth and current velocity were measured at each biologica] sampling device because these variables, in association with sediment and turbidity, can affect light penetration, scouring and sloughing of periphyton growth, and the makeup of the aquatic hjota. An effort was made to keep values for these variables as close as possible among and within stations.

\section{Algal Nutrjents}

Nitrogen and phosphorus are the two elements that most commonly limit the growth of algae in lakes and streams. Phosphorus is usually limiting in lakes because many common lake algae can use molecular nitrogen. Nitrogen fixing algae are not common in streams, therefore nitrogen is more often a limiting nutrient in flowing water. Only the soluble inorganic forms of these two nutriente--nitrate, nitrite and ammonia nitrogen and ortho-phosphate phosphorus--are readily available for plant uptake.

However, since even organically bound phosphorus is cycled much faster than nitrogen in aquatic systems, the concentration of total phosphorus in water 
Table 2. Water quality variables.

Physical variables

-Total suspended solids ( $\mathrm{mg} / \mathrm{l}$ )

-Turbidity (NTU)

-Secchi Disc transparency (feet)

-Streamflow (cubic ficet per second)

-Water depth (feet) and current velocity (feet per second)

Alga1 nutrients

$-\mathrm{NO}_{3}+\mathrm{NO}_{2}-\mathrm{N}, \mathrm{NH}_{3}+\mathrm{NH}_{4}-\mathrm{N}, \mathrm{PO}_{4}-\mathrm{P}$ and total. $\mathrm{P}$ (all in $\mathrm{mg} / 1$ )

-Total soluble inorganic nitrogen and total phosphorus as percentages of recommended maximum instream concentrations $(0.35 \mathrm{mg} / 1$ TSIN and $0.05 \mathrm{mg} / 1$ total $\mathrm{P}$ )

Periphyton production

-Chlorophyl1 a accrual 2 ( $\mathrm{mg} / \mathrm{m}^{2} /$ day)

- Biomass accrual (mg/m / day)

-Autotrophic index

-Chlorophy11 a/pheophytin a ratio (0D663 $\left.3_{\mathrm{b}} / 00663_{\mathrm{a}}\right)$

Periphyton community structure

-Abundance of non-diatom algae

-Percent relative abundance of diatom taxa

-Number of diatom taxa

-Diatom diversity (Shannon's index - $\vec{d}$ )

Macroinvertebrate community structure

-Percent relative abundance major macroinvertebrate orders

-Percent relative abundance major macroinvertebrate genera

-Number of macroinvertebrate genera

- Number of macroinvertebrate organisms

-Macroinvertebrate genus diversity (Shannon's index - $\bar{d}$ )

-Macroinvertebrate genus equitability (e) 
is a better indicator of algae growth potential than the concentration of ortho-phosphate phosphorus.

Phosphorus commonly attaches to particles of sediment, and concentrations of total phosphorus of ten are directly proportional to concentrations of total suspended solids and stream discharge. Nitrogen concentrations in Muddy Creek are largest during fall and winter at low flows. (See Figure 2.)

\section{Periphyton Production}

Periphyton or "slime" growth is a diverse assortment of algae, bacteria, fungi and microscopic animals, which live attached or in close proximity to the stream bottom. Algae are the producers of the stream bottom community; they use solar energy to convert basic raw materials into foodstuffs for the consumers: the microbes, macroinvertebrates and fish. If there are very few algae, chances are there will be very few fish as well. If algae are too numerous, they may be a nuisance and choke out other forms of life.

To estimate algae production the rate of accrual of chlorophy1l a was measured on artificial substrates. Chlorophyll a is the major photosynthetic pigment in plants. Also, the accumulation of biomass was measured. This represented the net growth of the entire periphyton community, of both producers (plants) and consumers (animals). The ratio of biomass to chlorophyll a--the autotrophic index--indicates the importance of consumers in the community relative to producers. As more nutrients and organic matter (fertilizer, sewage, manure, decomposing algae, etc.) are added to a stream, consumers multiply and the autotrophic index increases.

Pheophytin a is a physiologically inactive degradation product of chlorophyl1 a. The ratio of chlorophyll a to pheophytin a indicates the general condition or health of the algae in the periphyton.

\section{Periphyton Community Structure}

It is common for individual stream periphyton samples to contain from 100 to 200 species of algae, including representatives from severa 1 major divisions, such as the green, blue-green and golden-brown algae. These algae range in size from microscopic, single-celled and colonial forms to filaments a foot or more in length. Fach of them has specific water quality requirements (Palmer, 1977).

The group of algae known as the diatoms 1 s one of the most important in the periphyton commity. Diatoms are microscopic and unicellular golden-brown algae with cell walls composed of silica. These silica cell walls are ornamented--with a combination of dots and lines--in a manner that is unique to each species, making them easy to tell apart. Each of the many hundreds of diatom species found in fresh water is also unique in the conditions it requires for growth and a great deal of research has been directed at determining the environmental requirements and pollution tolerances of many of the more common species (Lowe, 1974). Consequent1y, many diatoms are useful indicators of water quality. 
The number of diatom species and the relative number of individuals per species are also indicators of water quality (Patrick and Reimer, 1966). Generally, unpolluted waters support many different species with none dominant. Waters polluted by organic wastes tend to have fewer species, including some that are represented by a relatively large number of individual cells. Because of the many species that are present, diatom associations in unpolluted waters are said to have high diversities, while those in organically polluted waters have low diversities. A widely accepted measure of diversity is Shannon's index (d), which considers the evenness of the distribution of individuals among the species as well as the total number of species present in a sample (Weber, 1973).

\section{Macroinvertebrate Community Structure}

Aquatic macroinvertebrates are animals that are large enough to be seen by the unaided eye, can be retained by a U.S. Standard No. 30 sieve and live at least part of their life cycles within or upon available substrates in a body of water (Weber, 1973). The major freshwater invertebrate groups are the insects, annelids, molluscs, flatworms, roundworms and crustaceans. They may be omnivores, carnivores or herbivores, detritus feeders, parasites, scavengers, grazers or predators. The macroinvertebrate community comprises the food and energy link between algae and fish.

Individual taxa within the macroinvertebrate community have specific environmental requirements and pollution tolerances just as do species of algae. Thus, macroinvertebrates may also be used to detect stress resulting from the introduction of pollutants. Because of the relatively long life spans of most macroinvertebrates (up to three years as compared to one or two days for diatoms) they reflect water quality conditions over a much longer period of time than do the diatoms and most other algae. Intermittent or infrequent pollutant discharges could easily escape detection by periodic chemical. sampling, but they may leave behind tell-tale changes in the makeup of a stream's macroinvertebrate community.

The number of taxa and the standing crop of macroinvertebrate organisms are sensitive to environmental disturbances and contaminants. Silt tends to reduce the number of taxa and the number of organisms in a macroinvertebrate community. Jnorganic nutrients generally have little effect on the number of taxa, but tend to increase the standing crop of organisms (Weber, 1973).

Commity diversity, as expressed by Shannon's index ( $\bar{d})$, is best suited for the detection of stress created by organic wastes. Silt and inorganic nutrients have varying effects on community diversity.

Equitability (e) is the component of diversity that is due to the distribution of individuals among the taxa. Fquitability is more sensitive to slight perturbations than is Shannon's index (Weber, 1983). And like Shannon's index, equitability is most useful in situations of organic pollution. 


\section{METHODS}

The device used to gather biological information is illustrated in Figure 3. Each device consisted of a steel fence post driven into the streambed, three plastic carriages loaded with eight microscope slides each, and a macroinvertebrate basket sampler made of half-inch hardware cloth and filled with a 2- to 3-inch dlameter crushed gravel. Three of these devices were installed at each water quality station in locations having similar depths and current velocities (Table 3). Depth and current velocity were measured with a Marsh-McBirney electronic current meter and a top-setting wading rod.

The three periphyton samplers were positioned just below the water surface, at mid-depth and just above the bottom (Figure 3). The surface sampler was supported with plastic foam floats and tethered to an eye bolt fastened near the top of the fence post. The mid-depth and bottom samplers were wired to a wooden lath, which was pressed into the stream bottom alongside the fence post and secured to the post with wire. Periphyton samplers were left in the river for two weeks.

The macroinvertebrate sampler was patterned after the basket sampler described by Anderson and Mason (1968) and measured $7 \frac{1}{2}$ inches by 6 inches by 4 inches. It was suspended as shown in Figure 3 about one-half foot of the river bottom to prevent it from silting in. Macroinvertebrate samplers were left in the river for five weeks.

\section{Physical Variables}

Water samples for analysis of algal nutrients, total suspended solids and turbidity were collected at each water quality station on placement and retrieval of the periphyton samplers. Secchi Disc transparency was measured at each station on placement of the samplers according to the method of Welch (1948). Streamflow data for Muddy Creek at Vaughn and the Sun River near Vaughn (below Muddy Creek) were provided by the U.S. Geological Survey, Water Resources Division, Helena. Discharge in the Sun River upstream from Muddy Creek was estimated by subtracting the Muddy Creek flow from the downstream Sun River flow.

One-pint samples for analysis of turbidity and total suspended solids were collected with a DH-48 depth-integrating sampler having a 0.25 -inch orifice. Samples were collected by the equal-width increment method (U.S.G.S., 1977) using 10 to 20 equally spaced points across the stream depending on stream width. At each point the sampler was lowered from the water surface to the streambed and back at the same rate. This method provides a water/sediment sample that is discharge weighted both vertically and laterally.

Samples were transported unpreserved to the D.H.E.S. Chemistry Laboratory in Helena. Turbidity was measured on a Hach Model $2100 \mathrm{~A}$ Turbidimeter. Total suspended solids concentrations were measured gravimetrically following filtration and evaporation at $105^{\circ} \mathrm{C}$ (E.P.A., 1979).

1 Periphytometer II T.M., Design Alliance Inc., Cincinnati, Ohio 45202 
Figure 3. Periphyton and macroinvertebrate sampling device.

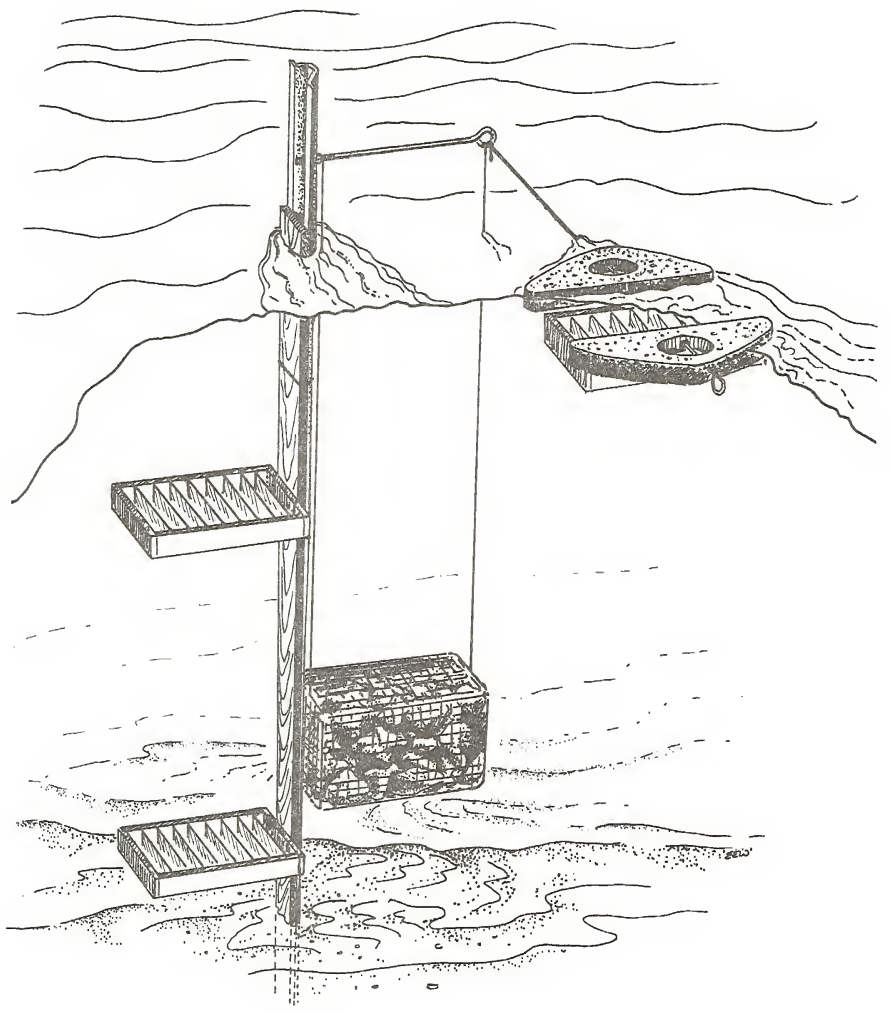




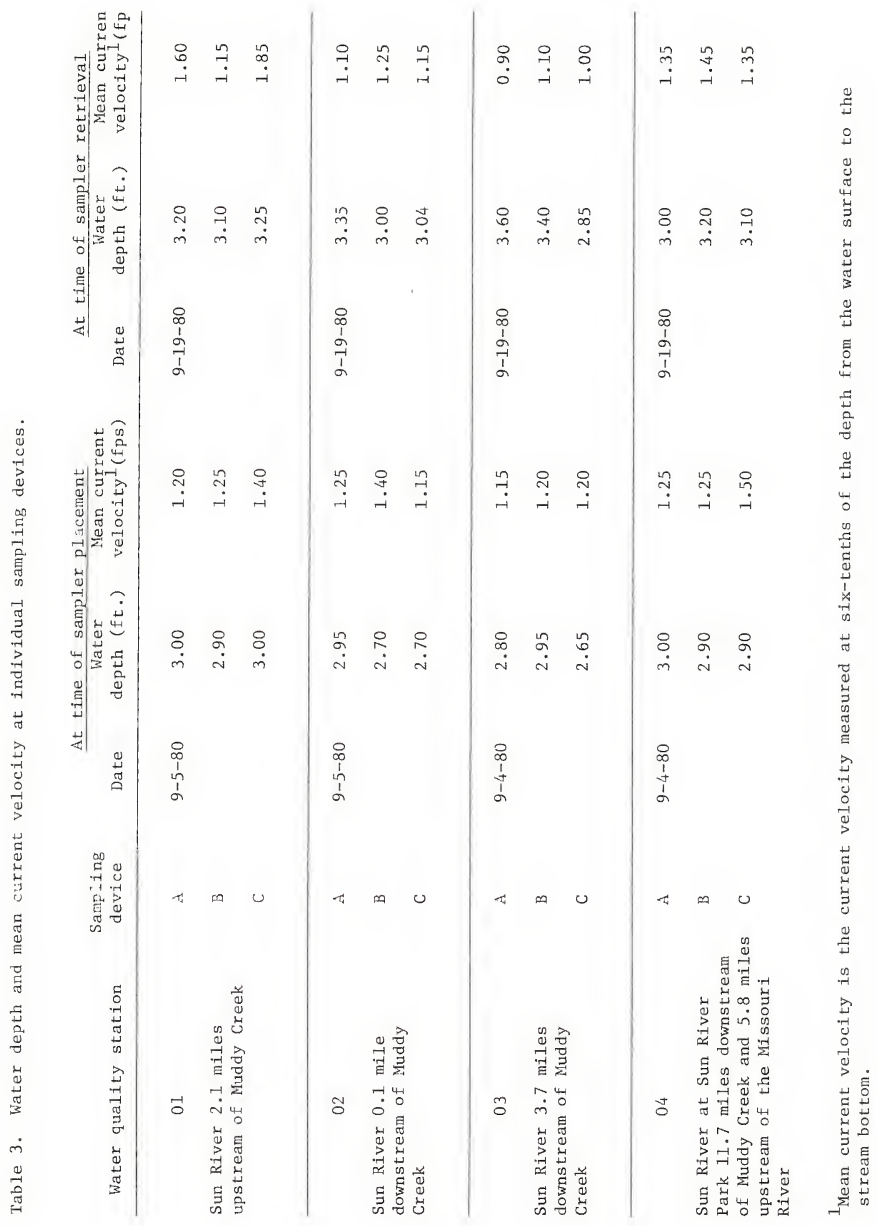


Unfiltered grab samples were collected at midstream in 1-1iter plastic bottles, preserved with $4 \mathrm{ml}$ of $1+\mathrm{H}_{2} \mathrm{SO}_{4}$ and transported on ice to the Chemistry Laboratory in Helena. Analytical procedures followed Standard Methods (A.P.H.A. et al., 1975) or those of the Environmental Protection Agency (1979). Orthophosphate was measured by the automated ascorbic acid, single reagent method. Total phosphorus was determined by persulfate digestion followed by the automated ascorbic acid method. Nitrate plus nitrite nitrogen was measured by the automated cadmium reduction method. And amonia nitrogen was measured by the automated phenolate method.

\section{Periphyton Production}

Seven slides were removed from each periphyton sampler for chlorophyll and biomass measurements. There were thus three seven-slide replicates for each depth at each station. The slides were placed in light-proof

microscope slide boxes, transferred to the laboratory on ice and stored in a freezer until they were processed.

Standard procedures were used to measure chlorophyll and biomass (A.P.H.A. et a1., 1975) with the following modifications. Periphyton from each seven-slide replicate was scraped into a foil-covered $100 \mathrm{ml}$ beaker. This material was washed into a foil-covered $50 \mathrm{ml}$ centrifuge tube with 10 $\mathrm{ml}$ volumes of a 90 percent acetone/10 percent saturated $\mathrm{MgCO}_{3}$ solution. From 10 to $40 \mathrm{ml}$ of extract solution was used depending on the amount of periphyton.

The tubes containing the chlorophyll extracts were placed in a sonic bath (high setting) for 30 minutes, allowed to steep for 24 hours in a refrigerator and sonified again for 30 minutes. The extract solutions were cleared by centrifugation and pigment optical densities were measured with a Perkin-Elmer Model 200 spectrophotometer at a resolution of $1.0 \mathrm{~nm}$ and a pathlength of 1 or $4 \mathrm{~cm}$.

The centrifuged periphyton material from each replicate was transferred to a $100 \mathrm{ml}$. Vycor evaporating dish and the remaining acetone was driven off under a bank of sun lamps. Biomass (ash-free weight) was measured according to Standard Methods (A.P.H.A. et al., 1975).

\section{Periphyton Community Structure}

One slide was removed from each periphyton sampler for analysis of periphyton community structure. The three slides representing a given depth at a given station were composited into a single sample. Periphyton was scraped from the slides into a bottle containing a small amount of river water and the sample was preserved with Lugols (IKI) solution.

The sample bottle was agitated to mix the contents and a small. subsample was immediately pipetted onto a microscope slide having a shallow depression. The subsample was covered with a glass slip and scanned at 100 and 400 magnifications. All non-diatom algae were identified to genus, 
assigned an abundance rating based on the approximate average number of cells per field of $v i e w$, and ranked according to estimates of their volume in the sample. Diatom genera were considered collectively in the rating and ranking.

A 10 to $20 \mathrm{ml}$ volume of agitated sample was poured into a small beaker. Concentrated sulfuric acid and a pinch of potassium dichromate were added under a fume hood to oxidize the organic matter, leaving behind only the silica cell walls of the diatoms. The acid was removed by repeated dilution and decantation with distilled water and $a_{3}$ permanent strewn mount of the cleaned diatoms was prepared using Hyrax ${ }^{3}$.

The strewn mount was scanned to prepare a list of diatom species and varieties. Then a proportional count was performed in which at least 200 and usually 400 diatom cells were identified and tallied. All diatom identifications were made at a magnification of 1000 with a Zeiss standard research microscope equipped with brightfield optics. The total number of taxa, the percent relative abundance of each taxon and Shannon's diversity index $(\bar{d})$ were calculated, the latter using the formula recommended by Weber (1973).

\section{Macroinvertebrate Community Structure}

Macroinvertebrate samplers were retrieved in a manner that prevented any loss of organisms. Each sampler was opened and the rocks emptied into a plastic tub, where they were scrubbed with s stiff-bristled brush to remove organisms and debris. The contents of the tub were poured through a II.S. Standard No. 50 sieve, flushed into a wide-mouth jar and preserved in 70 percent ethanol.

In the laboratory each sample was again emptied into a U.S. Standard No. 50 sieve and washed to remove silt and clay. The sample was then transferred to a white enameled pan. Organisms were located and picked from the debris using a 2 power illuminated magnifier, and identified to genus, if possible, with the ald of a stereomicroscope. Midges were identified only to family (Chironomidae).

Organisms were sorted and tallied by order and genus or family. The percent relative abundance of each taxon and the total number of taxa and organisms per sample were calculated. Shannon's diversity index ( $\bar{d}$ ) and equitability (e) were calculated using the formulas recommended by Weber (1973).

2Abundance ratings were assigned as follows:

Abundance rating

rare

common

very common

abundant

very abundant
Average number of cells per field of view at 100 magnifications

$$
\begin{aligned}
& 1 \text { or less } \\
& 2-4 \\
& 5-10 \\
& 11-99 \\
& 100 \text { or more }
\end{aligned}
$$

${ }^{3}$ Hyrax is a high refractive index mounting medium made by Custom Research and Development Inc., Auburn, California 95603. 


\section{RESULTS AND INTERPRETATIONS}

Only sumaries of the data generated during the Sun River biological study are presented in this chapter. Large tables of raw data, lists of biological organisms, and detailed statistical analyses using the student's $t$ test are appended to the end of the report. Results are herein compared with environmental norms and with data from other streams for the purpose of evaluating biological and water quality conditions.

\section{Physica] Variables}

Measurements of total suspended solids (TSS), turhidity and secchi Disc transparency are presented in Table 4 and Pigures 4 and 5 .

Streamflows in Muddy Creek and the Sun River during the study are graphed in Figure 6.

Streamflows generally subsided over the course of the study except for a peak centered around september 18. One-half inch of rainfall was recorded at nearby Fairfield from September 13 to 15 . Discharge increased abruptly in the Sun River and did not begin to decline until September 21. Turbidity and the concentration of TSS increased with discharge. Streamflows in Muddy Creek and the Sun River above Muddy Creek were nearly equal during the study.

The increases in TSS and turbidity and the decrease in Secchi Disc transparency from Station 03 to Station 04 are probably the result of incomplete mixing at Station 03. The fact that differences in TSS and turbidity values between these stations were proportionately smaller after the rainstorm than before may indicate more complete mixing of the Muddy Creek plume at the higher stage of the Sun River.

Fish yield generally decreases with increasing concentrations of suspended solids. Good to moderate fisheries can be maintained in waters that normally contain 25 to $80 \mathrm{mg} / 1$ TSS. Waters containing 80 to 400 or more $\mathrm{mg} / 1$ TSS are unlikely to support good freshwater fisheries (F.W.P.C.A., 1.968). Based on these criteria, the Sun River helow Muddy Creek is not likely to support a good fishery, especially during the peak of the irrigation season when the sediment contribution of Muddy Creek is much larger. (See Figure 2.)

The turbidity and Secchi Disc readings show how effectively the Muddy Creek sediment plume muddies the water and limits visibility in the Sun River. The light-attenuating effects of. Muddy Creek sediment are most clearly demonstrated by the periphyton production results.

\section{Algal Nutrients}

Concentrations of selected forms of nitrogen and phosphorus measured in the Sun River are given in Table 5. Concentrations of total soluble inorganic nitrogen (TSIN) and total phosphorus are displayed in Figures 7 and 8 .

Muddy Creek clearly enriched the Sun River with hoth nitrogen and phosphorus. Two features of these data beg explanation: (1) the increase 
Table 4. Total suspended solids (mg/1), turbidity (NTU) and a Secchi Disc transparency (feet) in the Sun River.

\begin{tabular}{|c|c|c|c|c|c|c|}
\hline \multirow[b]{2}{*}{ Station } & \multirow[b]{2}{*}{ Date } & \multicolumn{2}{|c|}{ Total suspended solids } & \multicolumn{2}{|c|}{ Turbidity } & \multirow{2}{*}{$\begin{array}{l}\text { Secchi Disc } \\
\text { transparency }\end{array}$} \\
\hline & & Value & Mean & Value & Mean & \\
\hline 01 & $\begin{array}{l}9-05-80 \\
9-19-80\end{array}$ & $\begin{array}{l}14.5 \\
31.4\end{array}$ & 23.0 & $\begin{array}{l}4.9 \\
9.8\end{array}$ & 7.4 & $>5.0$ \\
\hline 02 & $\begin{array}{l}9-05-80 \\
9-19-80\end{array}$ & $\begin{array}{l}175 \\
229\end{array}$ & 202 & $\begin{array}{l}27 \\
73\end{array}$ & 50 & 0.9 \\
\hline 03 & $\begin{array}{l}9-04-80 \\
9-19-80\end{array}$ & $\begin{array}{l}34.5 \\
71.9\end{array}$ & 53.2 & $\begin{array}{l}6.4 \\
27\end{array}$ & 17 & 1.8 \\
\hline 04 & $\begin{array}{l}9-04-80 \\
9-19-80\end{array}$ & $\begin{array}{l}74.5 \\
80.6\end{array}$ & 77.6 & $\begin{array}{l}14 \\
38\end{array}$ & 26 & 1.6 \\
\hline
\end{tabular}


Figure 4. Concentrations of total suspended solids in the Sun River.

( September 4 or 5,1980 and $=$ September $19,1980$.

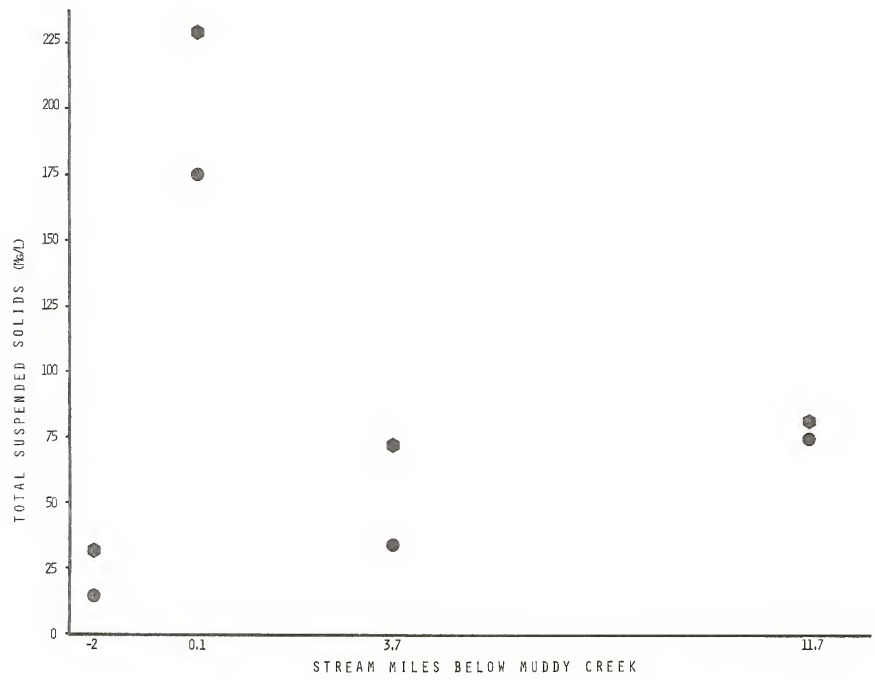


Figure 5. Turbidity in the Sun River. ( 0 = September 4 or 5, 1980 and - September 19, 1980.)

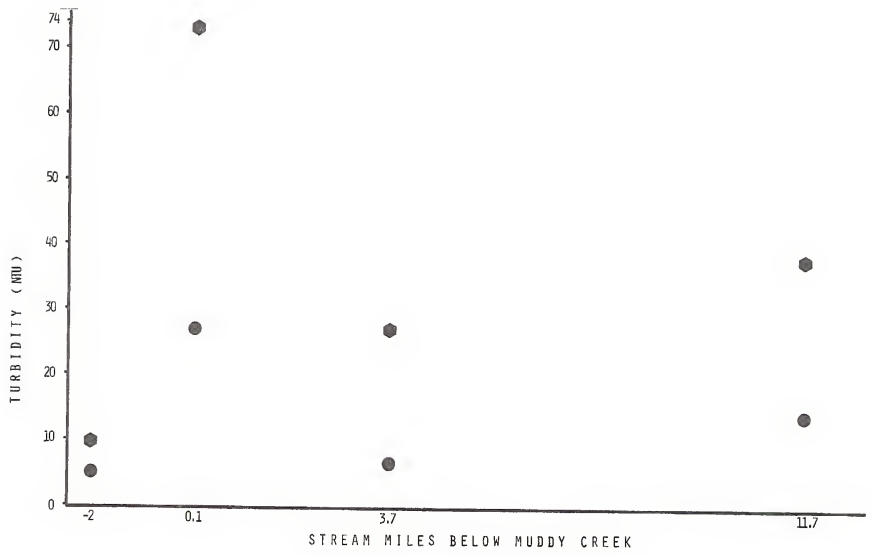


Figure 6. Discharge in Muddy Creek and the Sun River.

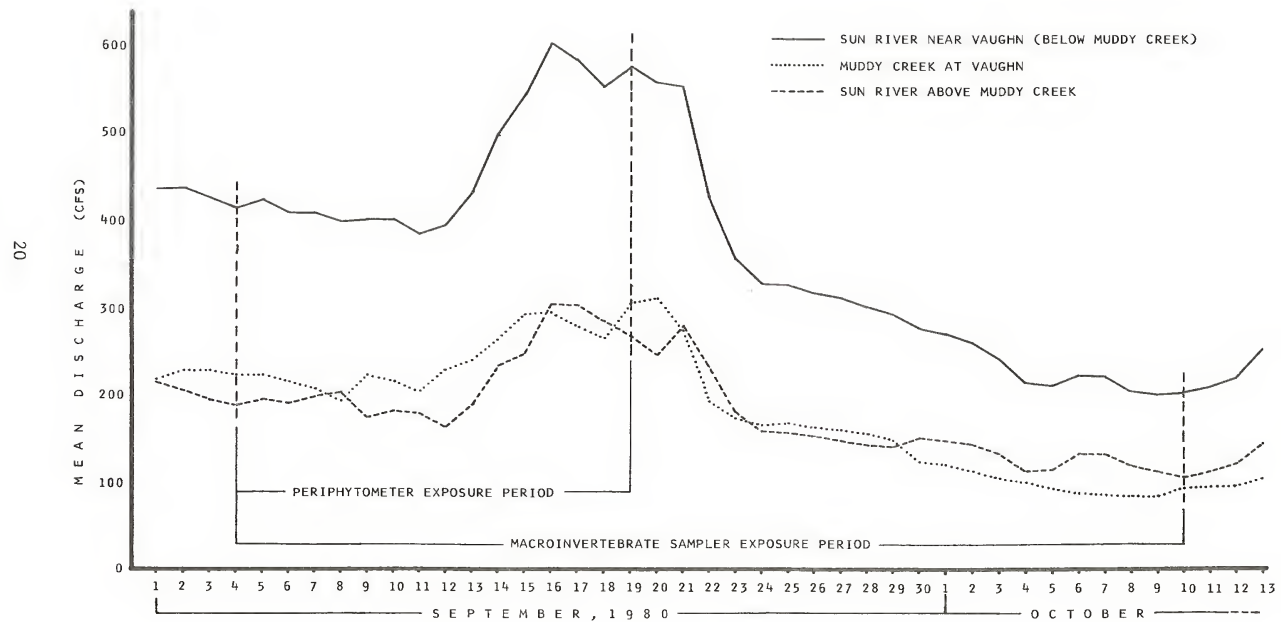


Table 5. Concentrations of algal nutrients (mg/l) in the Sun River.

\begin{tabular}{|c|c|c|c|c|c|c|}
\hline Station & Date & $\mathrm{NO}_{2}+\mathrm{NO}_{3}-\mathrm{N}$ & $\mathrm{NH}_{4}^{+}+\mathrm{NH}_{3-\mathrm{N}}$ & TSIN* & $\mathrm{PO}_{4}-\mathrm{P}$ & Total P \\
\hline 01 & $\begin{array}{l}9-05-80 \\
9-19-80\end{array}$ & $\begin{array}{l}0.16 \\
0.20\end{array}$ & $\begin{array}{l}<0.01 \\
<0.01\end{array}$ & $\begin{array}{l}0.16 \\
0.20\end{array}$ & $\begin{array}{r}<0.010 \\
0.016\end{array}$ & $\begin{array}{l}0.017 \\
0.033\end{array}$ \\
\hline 02 & $\begin{array}{l}9-05-80 \\
9-19-80\end{array}$ & $\begin{array}{l}0.65 \\
0.65\end{array}$ & $\begin{array}{r}0.04 \\
<0.01\end{array}$ & $\begin{array}{l}0.69 \\
0.65\end{array}$ & $\begin{array}{l}0.072 \\
0.147\end{array}$ & $\begin{array}{l}0.113 \\
0.180\end{array}$ \\
\hline 03 & $\begin{array}{l}9-04-80 \\
9-19-80\end{array}$ & $\begin{array}{l}0.27 \\
0.35\end{array}$ & $\begin{array}{l}0.06 \\
0.01\end{array}$ & $\begin{array}{l}0.33 \\
0.36\end{array}$ & $\begin{array}{l}0.015 \\
0.020\end{array}$ & $\begin{array}{l}0.029 \\
0.042\end{array}$ \\
\hline 04 & $\begin{array}{l}9-04-80 \\
9-19-80\end{array}$ & $\begin{array}{l}0.37 \\
0.40\end{array}$ & $\begin{array}{l}<0.01 \\
<0.01\end{array}$ & $\begin{array}{l}0.37 \\
0.40\end{array}$ & $\begin{array}{l}0.017 \\
0.023\end{array}$ & $\begin{array}{l}0.036 \\
0.044\end{array}$ \\
\hline
\end{tabular}

*Total soluble inorganic nitrogen is the sum of $\mathrm{NO}_{2}+\mathrm{NO}_{3}-\mathrm{N}$ plus $\mathrm{NH}_{4}^{+}+\mathrm{NH}_{3}-\mathrm{N}$. In computing TSIN concentrations, ammonia-nitrogen values below the detection Iimit $(0.01 \mathrm{mg} / 1)$ were considered to be zero. 
Figure 7. Concentrations of tota1. solub]e inorganic nitrogen in the Sun River. $(\mathrm{O}=$ September 4 or 5,1980 and $=$ September $19,1980$.

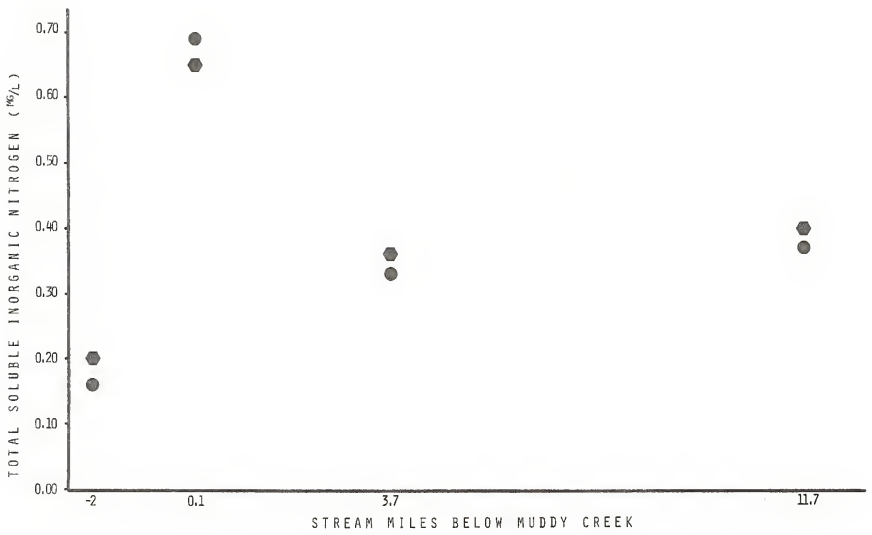


Figure 8. Concentrations of total phosphorus in the Sun River.

( $=$ September 4 or 5,1980 and $\quad$ September $19,1980$.

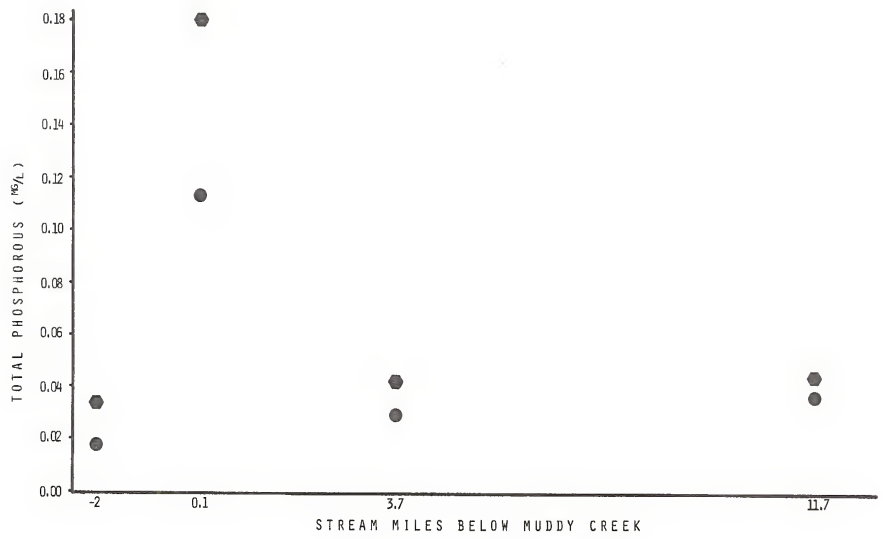


in concentrations of nutrients, particularly phosphorus, from the first date to the next, and (2) the apparent increase in nutrient concentrations from Station 03 to Station 04.

The September 13-15 rainstorm evidently washed soil particles into the creek and river, thereby raising the concentration of TSS. Phosphorus commonly attaches to soil particles carried by overland runoff, hence it would increase more sharply after a rainstorm than nitrogen, which does not attach to soil particles as readily.

TSIN actually decreased at Station 02 below Muddy Creek after the storm. One of the principal contributors of nitrogen to Muddy Creek (and the lower Sun River) is groundwater discharge from the Greenfields Irrigation District (Walther, 1982). This nitrogen was evidently diluted by surface runoff, which is consistent with evidence that nitrogen concentrations in Muddy Creek are inversely proportional to discharge (U.S.G.S., 1981).

Although there is at least one potential source of nutrients (a feedlot) between Station 03 and Station 04, the nutrient increase observed between these two stations is more likely the result of incomplete mixing at Station 03. Nutrient samples collected at Station 03 in midstream could have missed the plume of nitrogen-rich Muddy Creek water hugging the left (north) bank of the Sun River. Midstream nutrient concentrations would be larger after complete mixing, which they were at station 04 .

Zison and others (1977) suggest using the ratio of TSIN to orthophosphate to determine whether nitrogen or phosphorus is the limiting nutrient. If the ratio is larger than 10 , phosphorus is limiting; if the ratio is smaller than 5, nitrogen is limiting; if it 's between 5 and 10 , it's a toss-up. TSIN to orthophosphate ratios were larger than 10 at Stations 01,03 and 04 and between 5 and 10 at Station 02 . These results indicate that Sun River water was phosphorus limiting except just below Muddy Creek, which contributed relatively more phosphorus than nitrogen, especially after the September 13-15 rainstorm.

The D.H.E.S. has adopted the following maximum concentrations of TSIN and total phosphorus as guidelines for preventing nuisance algae growths in running waters:

$$
\begin{aligned}
& 0.35 \mathrm{mg} / 1 \mathrm{TSIN} \\
& 0.05 \mathrm{mg} / 1 \text { total phosphorus }
\end{aligned}
$$

TSIN and total phosphorus concentrations in the Sun River are expressed as percentages of these criteria in Tables 6 and 7 .

There is a potential for nuisance algae growth at Station 02 (and from the mouth of Muddy Creek to some distance below Station 02), where both TSIN and total phosphorus exceed their respective criteria. Excessive turbidity, abrasion and scouring by large concentrations of suspended solids, and an unstable bottom could and apparently do prevent such growths from developing. 
Table 6. Total soluble inorganic nitrogen $\left(\mathrm{NO}_{2}+\mathrm{NO}_{3}-\mathrm{N}\right.$ plus $\left.\mathrm{NH}_{4}^{+}+\mathrm{NH}_{3}-\mathrm{N}\right)$ as a percentage of the recommended maximum instream leve1 ( $0.35 \mathrm{mg} / 1)$.

\begin{tabular}{crrr} 
Station & Date & Value & Mean \\
\hline \multirow{2}{*}{01} & $9-05-80$ & 46 & 51 \\
& $9-19-80$ & 57 & \\
02 & $9-05-80$ & 197 & 191 \\
& $9-19-80$ & 186 & \\
03 & $9-04-80$ & 94 & 99 \\
& $9-19-80$ & 103 & \\
04 & $9-04-80$ & 106 & 110
\end{tabular}


Table 7. Total phosphorus as a percentage of the recommended maximum instream level $(0.05 \mathrm{mg} / 1)$.

\begin{tabular}{cccc} 
Station & Date & Value & Mean \\
\hline \multirow{2}{*}{01} & $9-05-80$ & 34 & 50 \\
& $9-19-80$ & 66 & \\
& & & \\
& & & \\
& $9-05-80$ & 226 & \\
& $9-19-80$ & 360 & \\
03 & & & \\
& $9-04-80$ & 58 & \\
& $9-19-80$ & 84 & \\
04 & & & \\
& $9-04-80$ & 72 &
\end{tabular}


Periphyton Production

Mean values for the periphyton production variables are presented in Table 8 . These values, together with confidence intervals representing plus or minus one standard deviation, are displayed in Figures 9 through 12. In the discussion that follows, "significant" changes in mean values are those based on a probability level of 0.90 or larger. This means there is less than one chance in ten that the observed difference is due to chance alone.

Chlorophy11 a accrual

Rates of chlorophy11 a accrual measured at the surface of the Sun River above and below Muddy Creek are comparable to those measured in the Yellowstone River through Billings (Klarich, 1976) and in other

"mesotrophic" streams in Montana (Bah1s et a1., 1979).

Mean values decreased immediately below Muddy Creek but returned to and surpassed control levels at the stations farther downstream. The ultimate downstream boost in primary productivity confirms that Muddy Creek enriched the Sun River with algal nutrients.

This enrichment was counteracted immediately below Muddy Creek, presumably by the large concentrations of total suspended solids (TSS) and high levels of turbidity, which shaded and possibly scoured the algae, particularly in deep water. A reduction in chlorophyll a accrual was pronounced at mid-depth and at the bottom of the first station below Muddy Creek. As TSS and turbidity levels ameliorated downstream, primary productivity rebounded.

Biomass accrua1

The response of biomass to Muddy Creek pollution was much the same as that of chlorophy11 a, except that the increase in biomass accrual was much larger than the increase in chlorophyll a accrual. This disproportionate recovery is clearly demonstrated by the autotrophic index (AI) values, which suggest enrichment by organic as we1l as inorganic nutrients.

Autotrophic index (AI)

Chlorophyl1 a contributes 1 to 2 percent of the total biomass in pure cultures of algae, hence communities composed exclusively of algae have biomass to chlorophy11 ratios (autotrophic index values) ranging from 50 to 100. As the fraction of consumers in a community increases, generally in response to organic pollution, the fraction of producers (algae) decreases, resulting in larger AI values. AI values typically range from 50 to 200 in unpolluted waters; much higher values indicate poor water quality (A.P.H.A. et al., 1975).

Mean AI values downstream from Muddy Creek were all larger than comparable upstream values and approached or exceeded the upper limit (200) for unpolluted waters. The largest AI values were recorded by the bottom samplers at the first two downstream stations. Values here were significantly larger than those recorded by surface samplers at the same 
Table 8. Mean values for periphyton production variables

\begin{tabular}{|c|c|c|c|c|c|}
\hline $\begin{array}{l}\text { Water quality } \\
\text { station }\end{array}$ & $\begin{array}{l}\text { Position of } \\
\text { periphyton } \\
\text { sampler }\end{array}$ & $\begin{array}{c}\text { Ch1orophy11 a } \\
\text { accrual } \\
\mathrm{mg} / \mathrm{m}^{2} / \text { day }\end{array}$ & $\begin{array}{c}\text { Blomass } \\
\text { accrua1 } \\
\mathrm{mg} / \mathrm{m}^{2} / \text { day }\end{array}$ & $\begin{array}{l}\text { Autotrophic } \\
\text { index }\end{array}$ & $\frac{\text { Ch1orophy11 a }}{\text { pheophyin a }}$ \\
\hline \multirow{3}{*}{01} & Surface & 1.44 & 133.60 & 96.54 & 1.73 \\
\hline & Mid-depth & 1.39 & 108.48 & 78.22 & 1.70 \\
\hline & Bot tom & 0.92 & 88.16 & 98.32 & 1.67 \\
\hline \multirow{3}{*}{02} & Surface & 1.00 & 141.86 & 149.99 & 1.65 \\
\hline & Mid-depth & 0.05 & 15.92 & 364.34 & 1.34 \\
\hline & Bottom & 0.02 & 19.77 & 893.60 & 1.51 \\
\hline \multirow{3}{*}{03} & Surface & 1.09 & 177.44 & 164.45 & 1.63 \\
\hline & Mid-depth & 1.22 & 190.48 & 157.41 & 1.58 \\
\hline & Bottom & 0.29 & 59.60 & 207.69 & 1.54 \\
\hline \multirow{3}{*}{04} & Surface & 2.14 & 436.92 & 222.21 & 1.63 \\
\hline & Mid-depth & 1.96 & 286.88 & 145.18 & 1.63 \\
\hline & Bottom & 1.30 & 111.95 & 102.76 & 1.65 \\
\hline
\end{tabular}


Figure 9. Mean values and confidence intervals for the rate of chlorophyll a accrual on artificial substrates in the Sun River. ( $\mathrm{O}=$ surface, $\Delta=$ mid-depth, and $=$ bottom. )

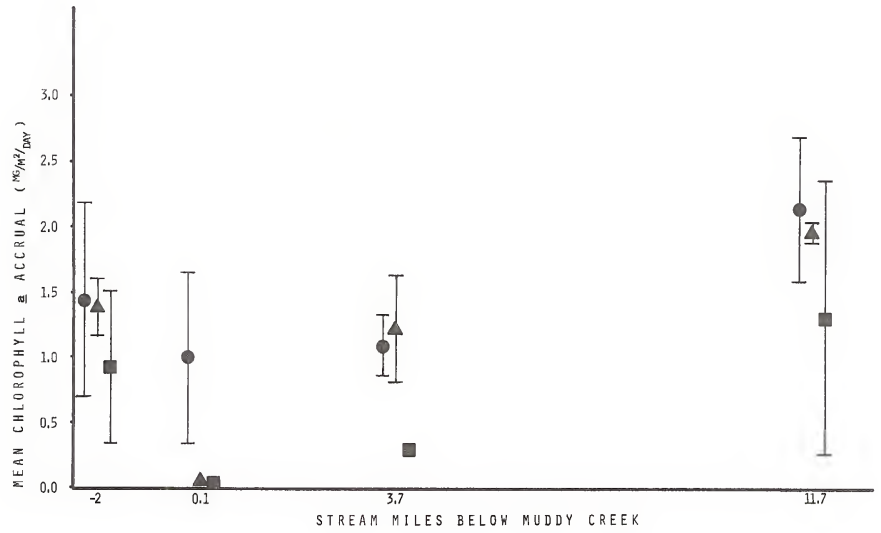


Figure 10. Mean values and confidence intervals for the rate of biomass accrual on artifical substrates in the Sun River. ( $0=$ surface, $\Delta=$ mid-depth, and = hottom.)

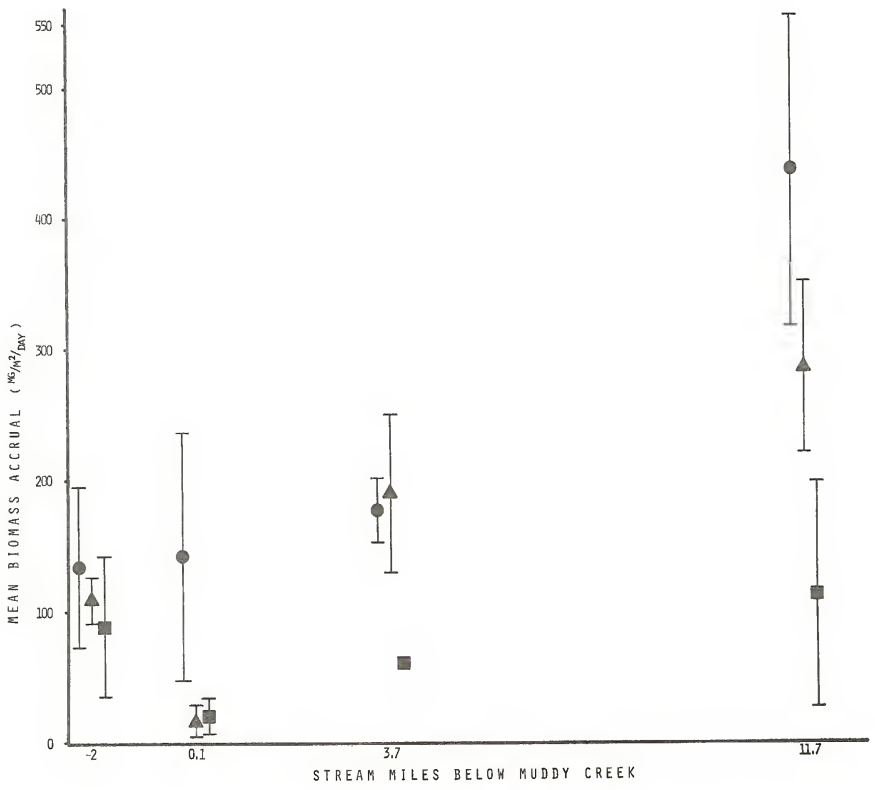


Figure 1.1. Mean values and confidence intervals for the autotrophic index of periphyton growths on artificial substrates in the Sun River.

( $=$ surface, $\Delta=$ mid-depth, and $\square=$ bottom.)

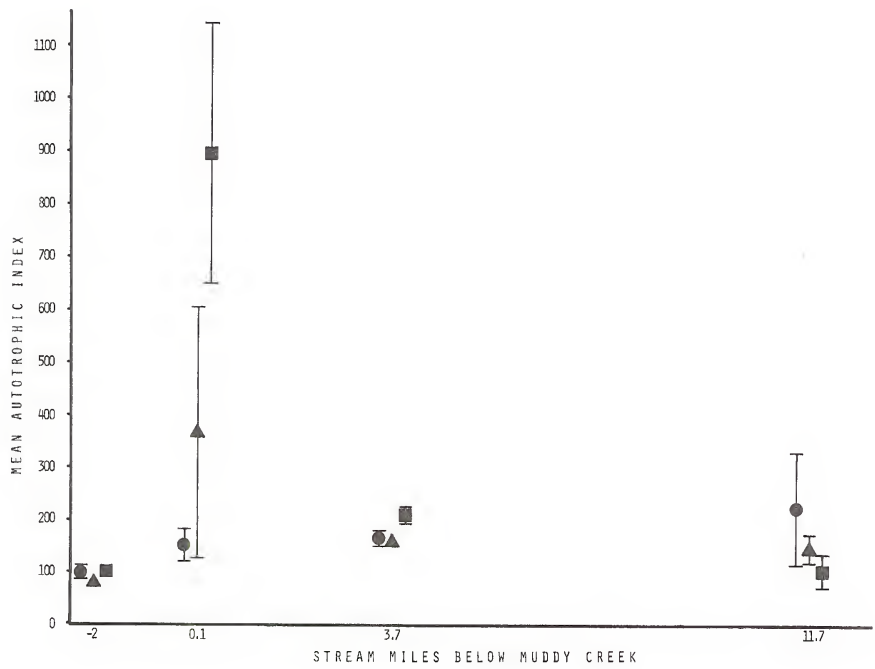


Figure 12. Mean values and confidence intervals for the chlorophyl1 a/pheophytin a ratio of periphyton growths on artificial substrates In the Sun River. ( $O=$ surface, $\Delta=$ mid-depth, and = bottom,)

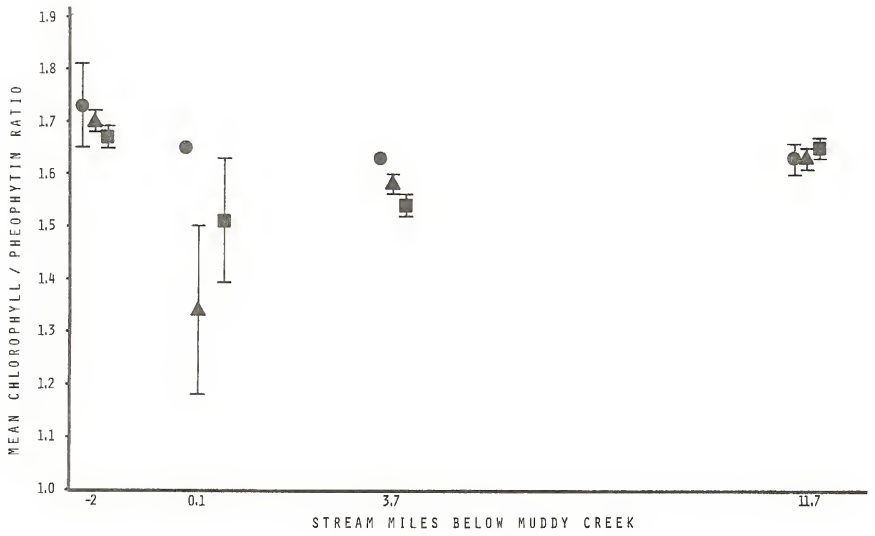


stations, which in turn were significantly larger than the value recorded by the surface sampler at the upstream station.

These results suggest that the sediment plume from Muddy Creek initially limited algae growth on the bottom of the Sun River by obscuring the sunlight required for photosynthesis. They also indicate that Muddy Creek enriched the Sun River with organic nutrients, which favored the growth of consumers over producers.

Chlorophy11 a/pheophytin a ratio

Ratios of chlorophyll a to pheophytin a range from about 1.7 in healthy periphyton communities to 1.0 in senescent or highly polluted communities completely lacking chlorophyll a. The data indicate that Muddy Creek did impair the physiological condition of Sun River algae and that the impairment was most severe near the river bottom in the first few miles below the confluence with Muddy Creek.

\section{Periphyton Community Structure}

Results of the analyses of periphyton community structure are summarized in Tables 9 and 10 and Figures 13 and 14 . Lists of algae taxa and their abundance values are appended to this report.

Abundance of non-diatom algae

Only two groups of algae were important in the Sun River besides the diatoms. These were the green and blue-green algae (Table 9).

The greens decreased in abundance and diversity immediately downstream from Muddy Creek, but the smaller and simpler forms reappeared in larger numbers farther downstream. Large filamentous green algae were common above Muddy Creek, but rare or absent at all stations below, presumably because they could not tolerate the abrasion and sedimentation of soil particles. Since many green algae require higher light intensities than other algae (Hynes, 1970), their initial decline below Muddy creek also may have been a function of shading by the dirty water.

Blue-green algae were rare above Muddy Creek, but common to very common in the clearing and nutrient-rich waters at the two downstream stations. Oscillatoria, which is an indicator of nutrient enrichment (Palmer, 1977), was the most common bluegreen at the two "recovery" stations.

Percent relative abundance of diatom taxa

Diatoms composed the most abundant algae group on every sampler at every station in the Sun River (Table 9). Of the 153 diatom taxa identified, seven exhibited large changes in percent relative abundance (PRA) from upstream to downstream of Muddy Creek. The most striking change was an order-of-magnitude decline in the PRA of Achnanthes minutissima, a normally clean-water diatom that requires a firm, stable substrate for anchorage. The void left by Achnanthes minutissima was filled by a number of motile and (or) nitrogen-loving taxa, which are better adapted to the 
Table 9. Number of genera and abundance (in parentheses) of algae in each of the four algal groups found on artificial substrates in the Sun River

$(\mathrm{R}=$ rare, $\mathrm{C}=$ common, $\mathrm{VC}=$ very common, $\mathrm{A}=$ abundant, $\mathrm{VA}=$ very abundant $)$.

\begin{tabular}{|c|c|c|c|c|c|}
\hline $\begin{array}{c}\text { Water quality } \\
\text { station }\end{array}$ & $\begin{array}{l}\text { Position of } \\
\text { periphyton } \\
\text { sampler }\end{array}$ & Diatoms & $\begin{array}{l}\text { Green } \\
\text { algae }\end{array}$ & $\begin{array}{l}\text { Blue-green } \\
\text { algae }\end{array}$ & $\begin{array}{l}\text { Euglenoid } \\
\text { algae }\end{array}$ \\
\hline 01 & $\begin{array}{l}\text { Surface } \\
\text { Mid-depth } \\
\text { Bottom }\end{array}$ & $\begin{array}{l}13 \text { (VA) } \\
11 \text { (VA) } \\
13 \text { (VA) }\end{array}$ & $\begin{array}{c}7(\mathrm{C}) \\
10(\mathrm{VC}) \\
8(\mathrm{C})\end{array}$ & $\begin{array}{l}2(R) \\
2(R) \\
2(R)\end{array}$ & $\begin{array}{l}0 \\
0 \\
0\end{array}$ \\
\hline 02 & $\begin{array}{l}\text { Surface } \\
\text { Mid-depth } \\
\text { Bottom }\end{array}$ & $\begin{array}{l}13 \text { (VA) } \\
11 \text { (C) } \\
14 \text { (C) }\end{array}$ & $\begin{array}{l}4(R) \\
1(R) \\
0\end{array}$ & $\begin{array}{l}1(R) \\
0 \\
1(R)\end{array}$ & $\begin{array}{l}0 \\
0 \\
0\end{array}$ \\
\hline 03 & $\begin{array}{l}\text { Surface } \\
\text { Mid-depth } \\
\text { Bottom }\end{array}$ & $\begin{array}{l}14 \text { (VA) } \\
16 \text { (A) } \\
15 \text { (VC) }\end{array}$ & $\begin{array}{l}6(\mathrm{VC}) \\
3(\mathrm{R}) \\
4(\mathrm{R})\end{array}$ & $\begin{array}{l}4 \text { (C) } \\
2 \text { (C) } \\
1 \text { (C) }\end{array}$ & $\begin{array}{l}0 \\
0 \\
0\end{array}$ \\
\hline 04 & $\begin{array}{l}\text { Surface } \\
\text { Mid-depth } \\
\text { Botton }\end{array}$ & $\begin{array}{l}14 \text { (VA) } \\
16(\mathrm{VA}) \\
12(\mathrm{VA})\end{array}$ & $\begin{array}{l}4(\mathrm{VC}) \\
3(\mathrm{VC}) \\
2(\mathrm{C})\end{array}$ & $\begin{array}{l}4(\mathrm{VC}) \\
1(\mathrm{C}) \\
1(\mathrm{VC})\end{array}$ & $\begin{array}{l}1(R) \\
0 \\
0\end{array}$ \\
\hline
\end{tabular}


Table 10. Diatom taxa showing large changes in percent relative abundance (PRA) downstream from Muddy Creek.

\begin{tabular}{|c|c|c|}
\hline Taxon & $\begin{array}{r}\text { Direction of } \\
\text { change in PRA } \\
\text { below Muddy Creek } \\
\end{array}$ & Ecological preferences \\
\hline Achnanthes minutissima & decrease & $\begin{array}{l}\text { stable substrates for } \\
\text { attachment (personal } \\
\text { observation) }\end{array}$ \\
\hline Diatoma vulgare & increase & $\begin{array}{l}\text { eutrophic waters (Lowe, 1974); } \\
\text { large nitrate concentrations } \\
\text { (Patrick and Reimer, 1966) }\end{array}$ \\
\hline$\frac{\text { Navicula }}{\text { var. tenella }}$ & increase & unknown \\
\hline$\frac{\text { Navicula }}{\text { var. intermedia }}$ & increase & unknown \\
\hline Navicula tripunctata & increase & eutrophic waters (Lowe, 1974) \\
\hline$\frac{\text { Navicula }}{\text { var. avenacea }}$ & increase & $\begin{array}{l}\text { similar to } \mathrm{N} \text {. viridula, } \\
\text { which prefers large } \\
\text { nitrate concentrations } \\
\text { (Patrick and Reimer, 1966) }\end{array}$ \\
\hline Nitzschia dissipata & increase & eutrophic waters (Lowe, 1974) \\
\hline
\end{tabular}


Figure 13. Total number of diatom taxa found on artificial substrates in the Sun River. ( $O=$ surface, $\Delta=$ mid-depth, and $\square=$ hottom.)

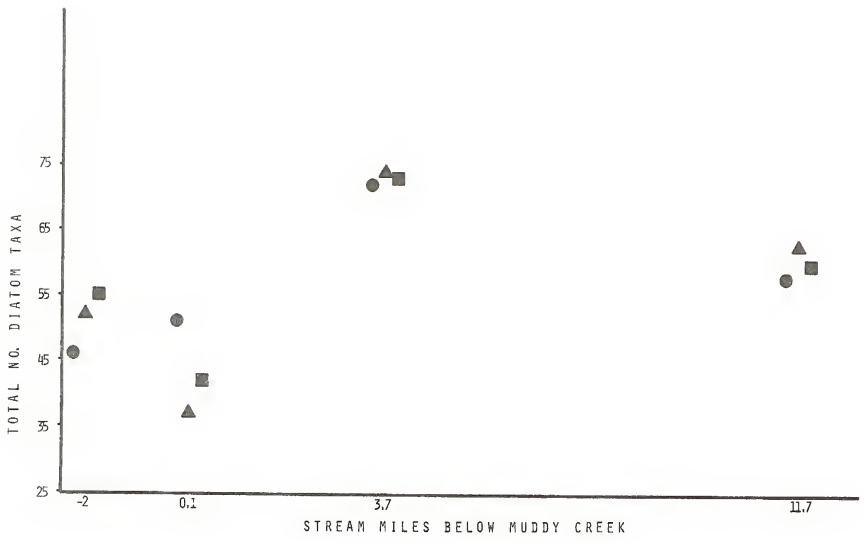


Figure 14. Species diversity (Shannon's index) for diatom associations found on artificial substrates $f 1$ the Sun River. $\mathbf{O}=$ surface, $\Delta=$ mid-depth, and $=$ bottom.)

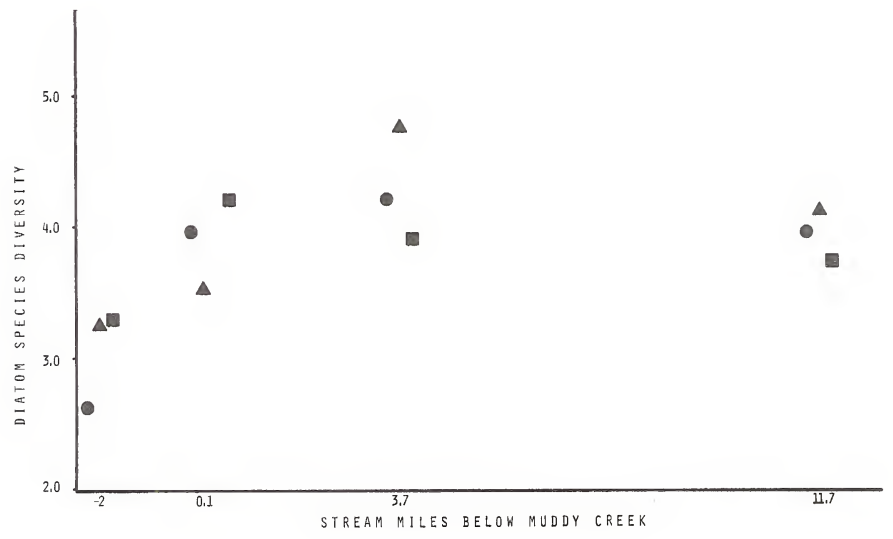


mesotrophic waters and unstable bottom downstream from Muddy Creek (Table 10).

Number of diatom taxa

The numbers of diatom taxa found on artificial substrates placed in the Sun River (Figure 13) were similar to those reported from natural substrates in unpolluted Montana streams (Bahls, 1979). The decline in total taxa below Muddy Creek probably reflects the physical impact of suspended solids, while the increase in tota.1 taxa farther downstream is apparently a function of environmental variability and perhaps modest nutrient enrichment.

Diatom diversity (Shannon's index -

Diatom diversity values (Figure 14) were also comparable to those reported by Bahls (1979) for unpolluted Montana streams. The smallest values were actually recorded above Muddy Creek, where specimens of one species (Achnanthes minutissima) accounted for about half of all the diatoms present, resulting in a very uneven distribution of individuals among the specles. With the less stable conditions below Muddy Creek, no one taxon could dominate the flora, and diversity improved. These data point out the danger in relying on biological diversity alone as a measure of water quality.

\section{Macroinvertebrate Community Structure}

Success at retrieving the basket samplers was 100 percent. However, Sampler C at Station 01 was prone to disturbance and on September 19 the authors witnessed the fence post supporting this sampler being jarred by a boat. Since organisms tend to evacuate disturbed samplers, setting back colonization time, and since results from samplers allowed to colonize for different lengths of time are not comparable (Brooks and Hilsenhoff, 1971), the data obtained from Sampler $C$ were excluded from statistical analyses and interpretations.

A total of 42 taxa was identified from the 12 samplers. The samplers contained from 293 to 4,240 organisms each, for a total of 19,749. Large amounts of organic detritus accumulated on most samplers and periphyton growth on the introduced rocks was fair to excellent at all stations except the one just below Muddy Creek.

In the discussion that follows, "significant" changes in mean values are those based on a probability level of 0.80 or larger. This means there are fewer than two chances out of ten that the observed difference is due to chance alone.

Percent relative abundance of major macroinvertebrate orders

True flies (Diptera), caddisflies (Trichoptera) and mayflies (Ephemeroptera) accounted for at least 94 percent of the macroinvertebrate organisms colonizing each basket sampler (Table 11 and Figure 15). From the station above to each of the first two stations below Muddy Creek, the proportion of caddisflies and mayflies increased and the proportion of true 
Table 11. Replicate and mean values for variables of macroinvertebrate community structure $($ PRA $=$ percent relative abundance $)$.

\begin{tabular}{|c|c|c|c|c|c|c|c|c|c|c|c|}
\hline \multirow{2}{*}{$\begin{array}{c}\text { Water } \\
\text { Quality } \\
\text { Station }\end{array}$} & \multirow[b]{2}{*}{ Replicate } & \multicolumn{10}{|c|}{ VARIABLES } \\
\hline & & 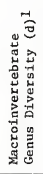 & 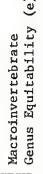 & 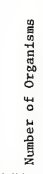 & 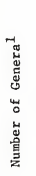 & 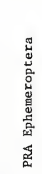 & 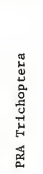 & 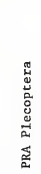 & 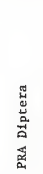 & 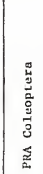 & 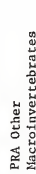 \\
\hline \multirow{3}{*}{01} & Mean & 2.31 & 0.33 & 2694 & 20 & 12.8 & 23.3 & 0.3 & 63.0 & 0.1 & 0.5 \\
\hline & A & 2.40 & 0.30 & 2336 & 23 & 12.9 & 30.6 & 0.4 & 55.4 & 0.1 & 0.6 \\
\hline & B & 2.23 & 0.35 & 3053 & 17 & 12.7 & 16.0 & 0.1 & 70.6 & $<0.1$ & 0.5 \\
\hline \multirow{4}{*}{02} & Mean & 3.08 & 0.54 & 421 & 22 & 23.2 & 37.8 & 2.8 & 33.4 & 2.0 & 0.8 \\
\hline & A & 3.21 & 0.57 & 402 & 23 & 26.4 & 46.0 & 4.5 & 21.1 & 1.5 & 0.5 \\
\hline & B & 3.01 & 0.46 & 567 & 24 & 23.4 & 30.9 & 3.4 & 40.7 & 1.1 & 0.5 \\
\hline & $c$ & 3.04 & 0.60 & 293 & 20 & 19.8 & 36.5 & 0.7 & 38.2 & 3.4 & 1.4 \\
\hline \multirow{4}{*}{03} & Mean & 2.20 & 0.35 & 744 & 18 & 27.0 & 27.7 & 0.1 & 44.2 & 0.3 & 0.7 \\
\hline & A & 1.99 & 0.36 & 739 & 14 & 21.0 & 23.8 & 0.0 & 54.8 & 0.0 & 0.4 \\
\hline & B & 2.29 & 0.37 & 802 & 19 & 29.3 & 27.1 & 0.1 & 41.9 & 0.5 & 1.1 \\
\hline & c & 2.33 & 0.33 & 691 & 21 & 30.8 & 32.1 & 0.1 & 36.0 & 0.3 & 0.6 \\
\hline \multirow{4}{*}{04} & Mean & 2.26 & 0.31 & 3429 & 21 & 11.8 & 29.8 & 2.4 & 55.3 & 0.1 & 0.6 \\
\hline & A & 2.41 & 0.37 & 2649 & 19 & 15.9 & 31.6 & 2.2 & 49.5 & 0.2 & 0.6 \\
\hline & B & 2.18 & 0.26 & 3397 & 23 & 9.7 & 28.8 & 2.6 & 58.2 & 0.1 & 0.7 \\
\hline & c & 2.20 & 0.30 & 4240 & 20 & 9.7 & 29.0 & 2.5 & 58.2 & 0.1 & 0.6 \\
\hline
\end{tabular}

${ }_{1}$ Midges were 1dentified only to family (Chironomidae) and counted as one genus. 
Figure 15. Mean percent relative abundance of organisms in the major macroinvertebrate orders colonizing basket samplers in the Sun River above and below Muddy Creek.

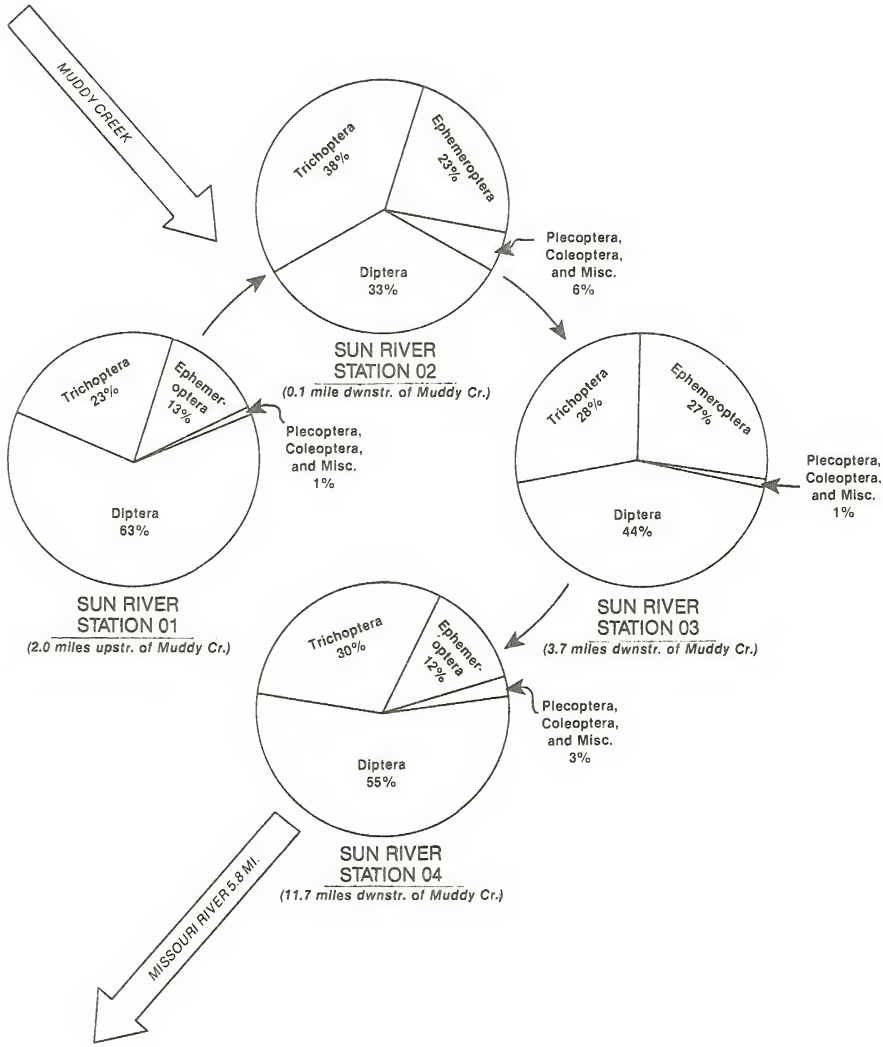


Figure 16. Mean values and confidence intervals for numbers of macroinvertebrate organisms colonizing basket samplers in the Sun River.

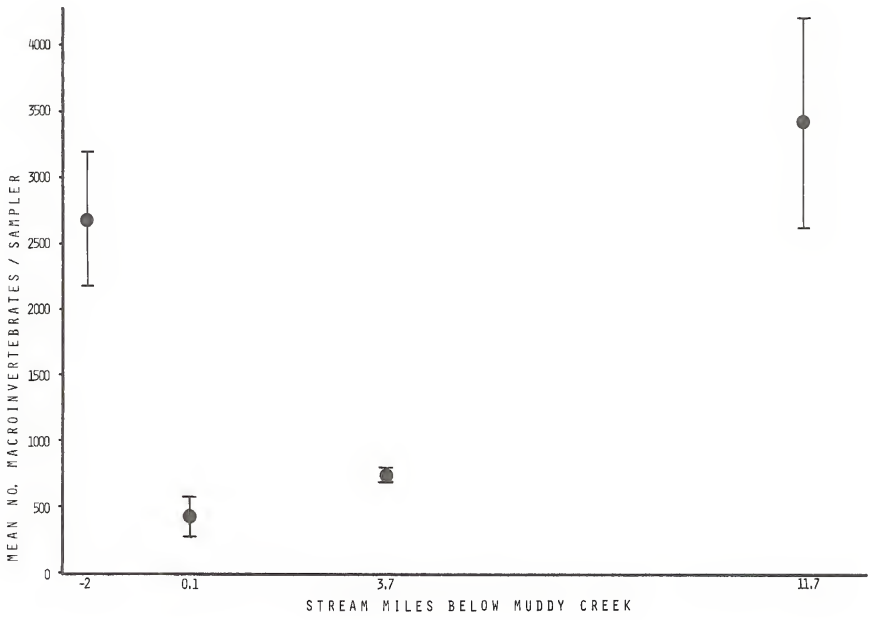


flies decreased; all hut one of the changes were significant. There were no significant differences $j n$ the relative importance of these three major orders between Station 01 and Station 04, suggesting biological recovery at the downstream station.

Percent relative abundance of major macroinvertebrate genera

Ten taxa accounted for 93 to 99 percent of the organisms colonizing each basket sampler (Table 12).

There was a large but not significant decline in percent relative abundance (PRA) of the black fly larva Simulium from above to below Muddy Creek. Simulium is a filter-feeding organisms that requires a stable substrate for anchorage and it is likely that Muddy Creek silt interferes with both the feeding and secure attachment of this animal. Since the midges were identified only to family and sfnce the genera of midges represent a variety of functional types (Merritt and Cumins, 1978), no solid explanation can he offered for their inittal decline and suhsequent recovery.

Hydropsyche and Cheumatopsyche are filter-feeding caddisflies (Merritt and Cummins, 1978) and their significant increases just downstream from Muddy Creek are likely in response to the sloughing algae and associated detritus particles observed entering the river from the creek. Heptagenia and Stenonema are mayflies that feed large]y by gathering their food (Merritt and Cumins, 1978). Their comparable increases downstream may likewise he due to the abundance of food particles originating in Muddy Creek. Apparently the large concentrations of jnorganic suspended solids released by Muddy Creek do not seriously interfere with the feeding of any of these four animals in the Sun River.

Tricorythodes and Ochrotrichia were the only genera whose PRA values were significant.ly Jarger at Station 04 than at each of the other three stations. Species of these genera are typical of depositional habitats (Merritt and Cummins, 1978), which well describes the Sun River at Station 04 as it slows on its approach to the Missouri River.

Baetis and Alloperla failed to show consistent or significant changes in PRA values from above to below Muddy creek.

Number of macroinvertebrate genera

There was a significant decline in the mean number of genera from Station 02 to Station 03 but otherwise the numbers were very similar (Table 11). Reasons for the apparent higher diversity at Station 02 compared with the other three stations are offered below.

\section{Number of macroinvertebrate organisms}

There was a significant and dramatic decline in the number of organisms colonizing the basket samplers from Station 01 to stations 02 and 03 (Table 1$]$ and Figure 16). Gammon (1970) reported that an increase of $120 \mathrm{mg} / 1$ suspended solids reduced macroinvertebrate density by 60 percent, but had no effect on species diversity. A comparable increase in tota] 


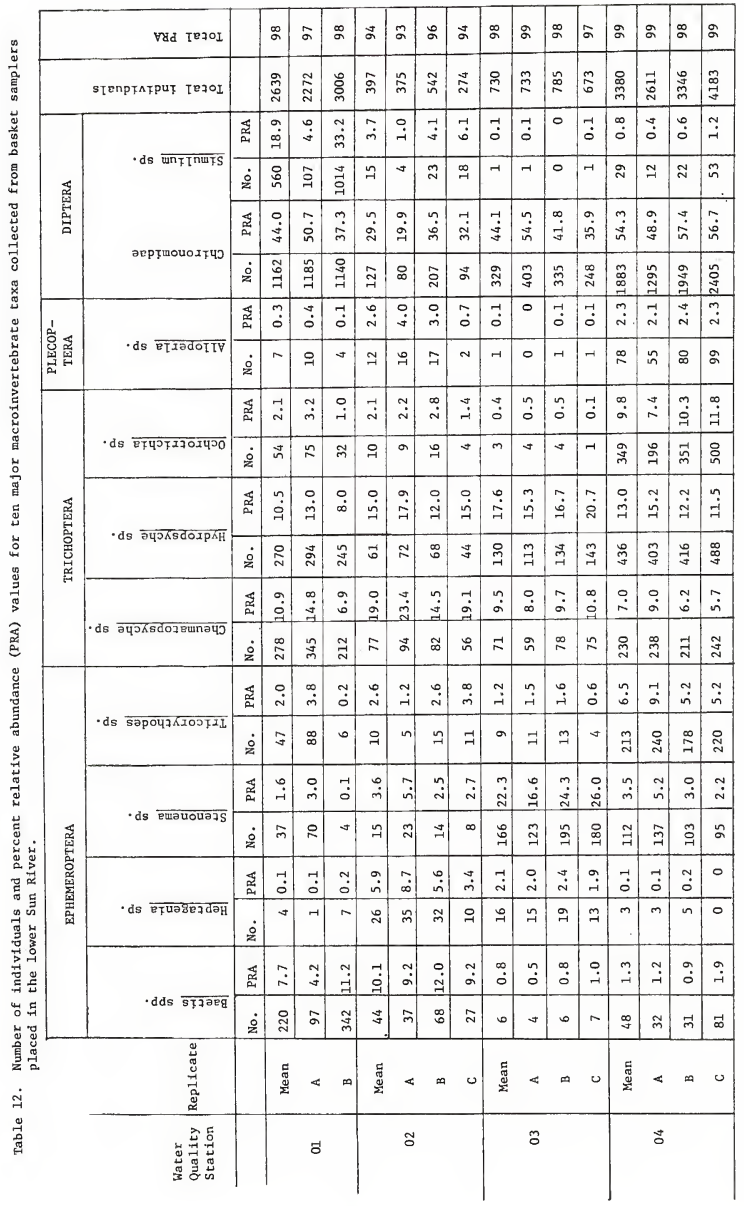


suspended solids occurred between Stations 01 and 02 during this study, resulting in a larger than 80 percent reduction in the number of organisms. The slight but not significant increase in mean number of organisms at Station 04 over the control station (01) may indicate recovery and enrichment.

Macroinvertebrate genus diversity (Shannon's index-- $\overline{\mathrm{d}}$ )

According to Wilhm (1970), diversity values larger than 2.6 indicate clean waters and those less than 2.0 indicate polluted waters. By this yardstick, only the station just below Muddy creek is pollution-free and the other three--including the control station--are of questionable quality (Table 11 and Figure 17). This is obviously not the case and there are several possible explanations.

First, Weher (1973) warns that diversity index values for fauna collected from artificial substrates must be evaluated with care because colonization is by chance, and diversity depends on the stage of community succession, which may vary with pollution loading. Second, Station 02 mav harbor a transitiona] fauna composed of representatives from both Muddy Creek and the upper Sun River; the higher diversity here could be a spatially-1imited artifact of this admixture. Third, midges were keyed only to family (Chironomidae) and counted as one genus. It is possible that fewer species were present just below Muddy Creek than at the other three stations. Fourth, the large number of Simulium at the control station depressed macroinvertebrate diversity much the same way that Achnanthes minutissima depressed diatom diversity at the same station.

As with diatom diversity, these data point out the danger in relying on biological diversity alone as a measure of water quality.

\section{Macroinvertebrate genus equitability (e)}

Equitability values (Table 11 and Figure 18) were just as misleading as diversity values and probab]y for many of the same reasons. According to Wilhm (1970), e values larger than 0.6 indicate clean waters and those less than 0.5 indicate polluted waters. By these criteria, Station 02 is borderline in quality and the other three are polluted. 
Figure 17. Mean values and confidence intervals for genus diversity (Shannon's index) of macroinvertebrate communities colonizing basket samplers in the Sun River.

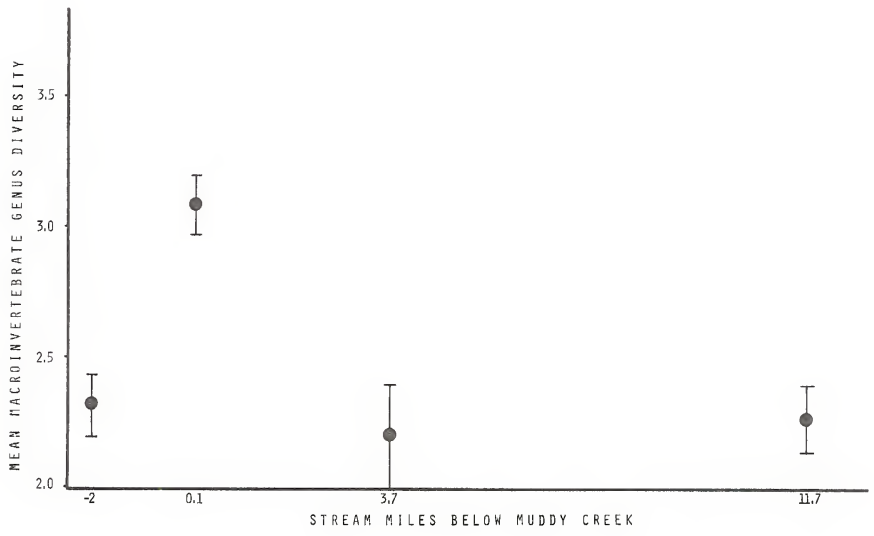


Figure 18. Mean values and confidence intervals for genus equitability (after Weber, 1973) of macroinvertebrate communities colonizing basket samplers in the Sun River.

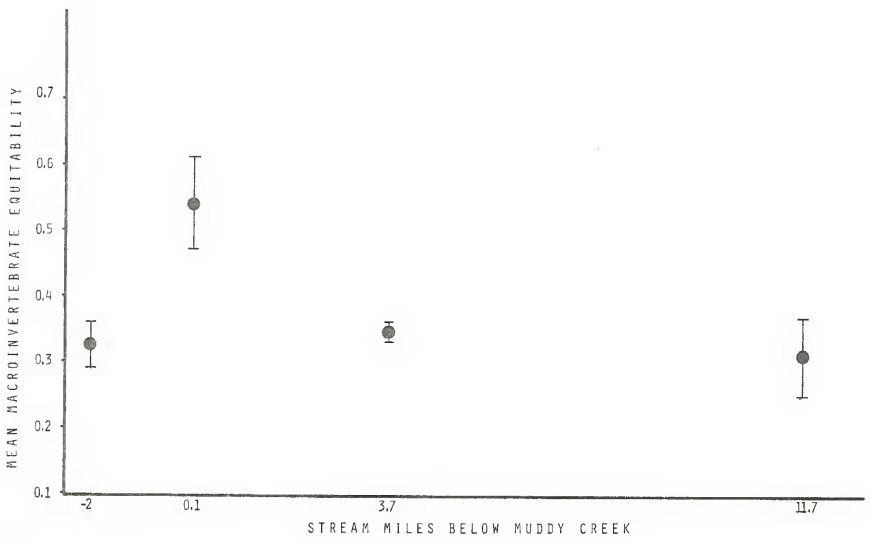


Based on the findings of this study, the Sun River is not likely to support a good fishery for the first $2.0 \mathrm{miles}$ below Muddy Creek. During the peak of the irrigation season when the sediment contribution of Muddy Creek is much larger, conditions for aquatic life will be worse, at times extending the impact zone all the way to the Missouri River at Great Falls.

Measures of diatom and macroinvertebrate diversity in the Sun River proved to be unreliable as indicators of the biological impact of the principal pollutants contained in the Muddy Creek plume, namely sediment and inorganic nutrients. Computed for both diatoms and macroinvertebrates, Shannon's diversity index $(\bar{d})$ and equitabiity (e) indicated that the cleanest, least polluted water was to be found in the Sun River at the station just below its confluence with Muddy Creek. These findings point out the danger in relying on blological diversity alone as a measure of water quality. 
American Public Health Association, American Water Works Association, and Water Pollution Control Federation. 1975. Standard methods for the examination of water and wastewater. 14th Edition. American Public Health Association, Washington, D.C.

Anderson, J.B. and W.T. Mason, Jr. 1968. A comparison of benthic macroinvertebrates collected by dredge and basket sampler. Journal Water Pollution Control. Federation 40:252-259.

Bah1s, T.I. 1979. Benthic diatom diversity as a measure of water quality. Proceedings Montana Academy of Sciences $38: 1-6$.

Bahls. L., M. Fillinger, R. Greene, A. Horpestad, G. Ingman, and E. Weber. 1979. Biological water quality monitoring, northwest Montana 1978-1979. Montana Department of Health and Environmental Sciences, Helena.

Brooks, J.G. and W.L. Hilsenhoff. 1971. Artificial substrate samples as indicators of water quality. Environmental Protection Agency, Cincinnati.

Environmental Protection Agency. 1979. Methods for chemical analysis of water and wastes. EPA-600/4-79-020.

Federal Water Pollution Control Administration. 1968. Water Quality Criteria. F.W.P.C.A., Washington, D.C.

Gammon, J.R. 1970. The effect of inorganic sediment on stream biota. F.P.A. water pollution control research series no. 18050DWC, G.P.O. Washington, D.C.

Hutchinson, G.F. 1957. A treatise on limology. Volume I. Geography, physics and chemistry. John Wiley and Sons, Inc., New York.

Hynes, H.B.N. 1970. The ecology of running waters. University of Toronto Press, Toronto.

Ingman, G.L., L.I. Bah1s, and A.A. Horpestad. 1979. Biological water quality monitoring, northcentral Montana 1977-1978. Montana Department of Health and Environmental Sciences, Helena.

Rlarich, D.A. 1976. Estimates of primary production and periphyton community structure in the Yellowstone River (Laurel to Huntley, Montana). Montana Department of Health and Environmental Sciences, Billings.

Lowe, R.I. 1974. Environmental requirements and pollution tolerance of freshwater diatoms. EPA-670/4-74-005.

Merritt, R.W., and K.W. Cummins (eds.). 1978. An introduction to the aquatic insects of North America. Kendall/Hunt Publishing Company, Dubuque, Iowa. 
Palmer, C.M. 1977. Algae and water pollution. FPA-600/9-77-036.

Patrick, R., and C.W. Reimer. 1966. The diatoms of the United States. Volume 1. Monograph No. 13, The Academy of Natural sciences of Philadelphia.

Systems Technology. 1979. Muddy Creek special water quality project. Systems Technology, Tnc., Helena.

U.S. Geological Survey. 1977. National handbook of recommended methods for water-data acquisition. Office of Water Data Coordination, U.S. Genlogical Survey, Reston, Virginia.

U.S. Geological Survey. 1981. Water resources data for Montana. Water year 1980. Volume 1. U.S. Geological Survey Water-data Report MT-80-1. Water Resources Division, Helena.

Walther, K.C. 1981. Nitrates in wells of the Greenfields Irrigation District, Fairfield, Montana. Montana Department of Health and Environmental Sciences, Helena.

Walther, K.C. 1982. Nutrients in Muddy Creek and wastewater drains of the Greenfields Irrigation District. Montana Department of Ilea1th and Environmental. Sciences, Helena.

Water Quality Bureau. 1982. Montana water quality, 1982. Montana Department of Health and Environmental Sciences, Helena.

Weber, C.I. (ed.). 1973. Biological field and laboratory methods for measuring the quality of surface waters and eff]uents. EPA-670/4-73-001. Welch, P.S. 1948. Limnological methods. McGraw-Hill Book Company, New
York.

Wilhm, J.I. 1970. Range of diversity index in benthic macroinvertebrate populations. Journal Water Pollution Control Federation 42:R221-R224.

Zison, S.W., K.F. Haven, and W.B. Mills. 1977. Water quality assessment: A screening method for nondesignated 208 areas. EPA-600/9-77-023. 
A PPENDIX 

Table 13. Values for periphyton production variables measured on artificial substrates in the Sun River.

Station 01

Floating Sampler

$\begin{array}{ll}\text { Ch1oro- } & \text { Ch1oro- } \\ \text { phyl1 } & \text { phyl1 } \\ \left(\mathrm{mg} / \mathrm{m}^{2}\right) & \underline{\left(\mathrm{mg} / \mathrm{m}^{2}\right)}\end{array}$

$\begin{array}{ll} & \text { replicate C } \\ & \text { mean } \\ \text { Mid-depth } & \text { standard deviation } \\ \text { Sampler } & \text { replicate A } \\ & \text { replicate B } \\ & \text { replicate C } \\ & \text { mean } \\ \text { Bottom } & \text { standard deviation } \\ \text { Sampler } & \text { replicate A } \\ & \text { replicate B } \\ & \text { replicate C } \\ & \text { mean } \\ & \text { standard deviation }\end{array}$

$\begin{array}{rrrrrrrrr}21.08 & 1.20 & 3.06 & 1.82 & 2.09 & 1.51 & 1820.95 & 130.07 & 86.37 \\ 9.29 & 0.72 & 1.65 & 1.69 & 2.01 & 0.66 & 1036.19 & 74.01 & 111.51 \\ 30.02 & 2.77 & 6.58 & 1.69 & 2.06 & 2.14 & 2754.29 & 196.73 & 91.75 \\ 20.13 & 1.56 & 3.76 & 1.73 & 2.05 & 1.44 & 1870.48 & 133.60 & 96.54 \\ 10.40 & 1.07 & 2.54 & 0.08 & 0.04 & 0.74 & 860.12 & 61.44 & 13.24 \\ 22.77 & 1.70 & 4.74 & 1.71 & 2.07 & 1.63 & 1801.90 & 128.71 & 79.14 \\ 16.71 & 1.12 & 3.53 & 1.70 & 2.04 & 1.19 & 1371.43 & 97.96 & 82.08 \\ 18.83 & 1.16 & 3.89 & 1.68 & 2.08 & 1.35 & 1382.86 & 98.78 & 73.43 \\ 19.44 & 1.33 & 4.05 & 1.70 & 2.06 & 1.39 & 1581.73 & 108.48 & 78.22 \\ 3.08 & 0.32 & 0.62 & 0.02 & 0.02 & 0.22 & 245.30 & 17.52 & 4.40 \\ 10.01 & 0.63 & 2.44 & 1.65 & 2.09 & 0.72 & 860.95 & 61.50 & 85.98 \\ 6.42 & 0.45 & 1.88 & 1.68 & 2.15 & 0.46 & 731.43 & 52.24 & 113.84 \\ 22.18 & 1.82 & 5.51 & 1.69 & 2.06 & 1.58 & 2110.48 & 150.75 & 95.15 \\ 12.87 & 0.97 & 3.28 & 1.67 & 2.10 & 0.92 & 1234.29 & 88.16 & 98.32 \\ 8.26 & 0.74 & 1.95 & 0.02 & 0.05 & 0.59 & 761.56 & 54.40 & 14.20\end{array}$


Table 13. Continued

Station 02

Floating

Sampler

replicate $A$

replicate $B$

replicate $\mathrm{C}$

mean

standard deviation

Mid-depth

N
Sampler replicate $B$

replicate $\mathrm{C}$

mean

standard deviation

Botton

Sampler

\begin{tabular}{lll} 
Ch1oro- & Ch1oro- & Ch1oro- \\
phy11 a & phy11 b & phyl1 \\
$\left(\mathrm{mg} / \mathrm{m}^{2}\right)$ & $\underline{\left(\mathrm{mg} / \mathrm{m}^{2}\right)}$ & $\left(\mathrm{mg} / \mathrm{m}^{2}\right)$ \\
\hline
\end{tabular}

Ch1oro-

a ratio heophytin Stability phy11 a
Biomass

$\left(\mathrm{mg} / \mathrm{m}^{2}\right)$
Biomass Auto-

Accrual trophic

(mg/m $/ \mathrm{m}^{2} /$ day) Index

\begin{tabular}{|c|c|c|c|c|c|c|c|c|}
\hline 3.27 & 0.19 & 0.74 & 1.66 & 1.99 & 0.23 & 563.81 & 40.27 & 172.40 \\
\hline 19.80 & 0.78 & 5.42 & 1.64 & 2.11 & 1.41 & 3188.57 & 227.76 & 161.02 \\
\hline 18.53 & 0.76 & 4.53 & 1.65 & 2.07 & 1.35 & 2205.71 & 157.55 & 116.02 \\
\hline 14.00 & 0.58 & 3.56 & 1.65 & 2.06 & 1.00 & 1986.03 & 141.86 & 149.99 \\
\hline 9.30 & 0.34 & 2.49 & 0.01 & 0.06 & 0.66 & .1326 .10 & 94.72 & 29.51 \\
\hline-- & -- & -- & -- & MISSING & -- & -- & -- & -- \\
\hline 0.64 & 0.05 & 0.20 & 1.49 & 2.16 & 0.05 & 342.86 & 24.49 & 533.91 \\
\hline 0.53 & 0.05 & 0.20 & 1.18 & 2.20 & 0.04 & 102.86 & 7.35 & 194.76 \\
\hline 0.59 & 0.05 & 0.20 & 1.34 & 2.18 & 0.05 & 222.86 & 15.92 & 364.34 \\
\hline 0.06 & 0.00 & 0.00 & 0.16 & 0.03 & 0.01 & 169.71 & 12.12 & 239.82 \\
\hline 0.18 & 0.05 & 0.17 & 1.44 & 2.26 & 0.01 & 194.29 & 13.88 & 1060.62 \\
\hline 0.49 & 0.10 & 0.22 & 1.45 & 2.33 & 0.03 & 491.43 & 35.10 & 1007.70 \\
\hline 0.24 & 0.09 & 0.21 & 1.65 & 2.30 & 0.02 & 144.76 & 10.34 & 612.49 \\
\hline 0.30 & 0.08 & 0.20 & 1.51 & 2.30 & 0.02 & 276.83 & 19.77 & 893.60 \\
\hline 0.16 & 0.03 & 0.03 & 0.12 & 0.04 & 0.01 & 187.49 & 13.39 & 244.88 \\
\hline
\end{tabular}


Table 13. Continued

Station 03

Floating
Sampler

$\omega$

replicate A
replicate B
replicate C
mean
standard deviation
replicate A
replicate B
replicate C
mean
standard deviation
replicate A
replicate B
replicate C
mean

standard devfation

\begin{tabular}{lll} 
Ch1oro- & Ch1oro- & Ch1oro- \\
phy11 a & phy11 b & phy11 \\
$\left(\mathrm{mg} / \mathrm{m}^{2}\right)$ & $\left(\mathrm{mg} / \mathrm{m}^{2}\right)$ & $(\mathrm{mg} / \mathrm{m} 2)$ \\
\hline
\end{tabular}

Chloro-
phyll a

Choro-

Phylin Stability Accrual

a ratio Index ${ }^{1}$

Accrual
$\left(\mathrm{mg} / \mathrm{m}^{2} /\right.$ day $)$

Biomass

Biomass
$\left(\mathrm{mg} / \mathrm{m}^{2}\right)$

Bionass
Accrual

Accrual
$\left(\mathrm{mg} / \mathrm{m}^{2} /\right.$ day $)$

Auto-

rophic Index

$\begin{array}{rrrrrrrrr}18.07 & 1.19 & 4.89 & 1.63 & 2.03 & 1.20 & 2734.24 & 182.35 & 151.34 \\ 12.44 & 0.98 & 3.43 & 1.64 & 2.01 & 0.83 & 2266.67 & 151.11 & 182.16 \\ 18.66 & 1.31 & 4.76 & 1.62 & 2.01 & 1.24 & 2982.86 & 198.86 & 159.86 \\ 16.39 & 1.16 & 4.36 & 1.63 & 2.02 & 1.09 & 2661.26 & 177.44 & 164.45 \\ 3.43 & 0.17 & 0.81 & 0.01 & 0.01 & 0.23 & 363.63 & 24.25 & 15.92 \\ 22.61 & 1.01 & 5.68 & 1.58 & 2.13 & 1.51 & 3649.52 & 243.30 & 161.43 \\ 21.09 & 0.99 & 5.17 & 1.60 & 2.11 & 1.19 & 3062.52 & 204.19 & 145.20 \\ 11.23 & 0.60 & 2.74 & 1.56 & 2.15 & 0.75 & 1859.05 & 123.94 & 165.60 \\ 18.31 & 0.87 & 4.53 & 1.58 & 2.13 & 1.22 & 2857.14 & 190.48 & 157.41 \\ 6.18 & 0.23 & 1.57 & 0.02 & 0.02 & 0.41 & 912.79 & 60.85 & 10.78 \\ 4.36 & 0.26 & 1.00 & 1.52 & 2.16 & 0.29 & 891.43 & 59.43 & 204.60 \\ 4.19 & 0.33 & 0.84 & 1.55 & 2.14 & 0.28 & 940.95 & 62.73 & 224.77 \\ 4.36 & 0.26 & 0.87 & 1.54 & 2.13 & 0.29 & 849.52 & 56.64 & 193.69 \\ 4.31 & 0.28 & 0.90 & 1.54 & 2.14 & 0.29 & 893.97 & 59.60 & 207.69 \\ 0.10 & 0.04 & 0.09 & 0.02 & 0.02 & 0.01 & 45.77 & 3.05 & 15.77\end{array}$


Table 13. Continued

\begin{tabular}{|c|c|c|c|c|c|c|c|c|c|}
\hline Station 04 & $\begin{array}{l}\text { Chloro- } \\
\text { phyl1 a } \\
\left(\mathrm{mg} / \mathrm{m}^{2}\right)\end{array}$ & $\begin{array}{l}\text { Chlora- } \\
\text { phyl1 b } \\
\left(m g / m^{2}\right)\end{array}$ & $\begin{array}{l}\text { Chloro- } \\
\text { phy11 } \\
\left(\mathrm{mg} / \mathrm{m}^{2}\right)\end{array}$ & $\begin{array}{l}\text { Clora- } \\
\text { phy } 11 \text { a/ } \\
\text { Pheophytin } \\
\text { a ratio }\end{array}$ & $\begin{array}{l}\text { Stability } \\
\text { Index } 1\end{array}$ & $\begin{array}{l}\text { Chloro- } \\
\text { phyl1 a } \\
\text { Accrual } \\
\text { (mg/m²/day) }\end{array}$ & $\begin{array}{l}\text { Biomass } \\
\left(\mathrm{mg} / \mathrm{m}^{2}\right)\end{array}$ & $\begin{array}{c}\text { Biomass } \\
\text { Accrual } \\
\text { (ng } / \mathrm{m}^{2} / \text { day) }\end{array}$ & $\begin{array}{l}\text { Auto- } \\
\text { trophic } \\
\text { Index }\end{array}$ \\
\hline
\end{tabular}

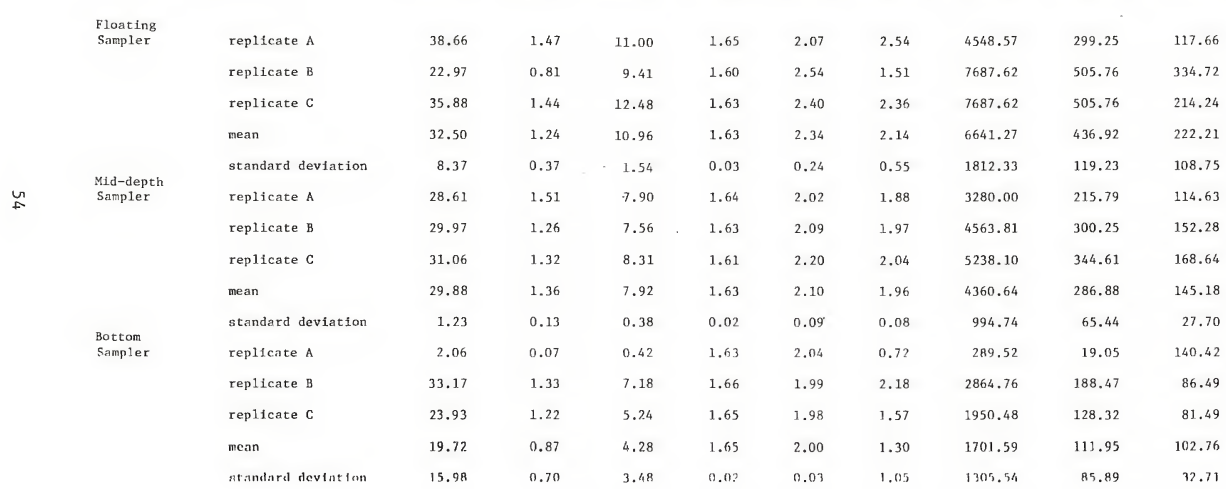

1 Ratio of yellow pigments to green pigments $\left(\mathrm{OD}_{430} / \mathrm{OD}_{663}\right)$; values around 2 indicate vigorous, young periphyton communities (Odum, E.P. 1963. Ecology. Holt, Rinehart and Winston, New York, 152 pp.). 
Table 14. Significance of differences between stations in mean values for periphyton production variables, using calculated $t$ values and appropriate degrees of freedom.

\begin{tabular}{|c|c|c|c|c|c|c|c|c|}
\hline \multicolumn{9}{|c|}{ PERIPHYTON PRODUCTION VARIABLES } \\
\hline 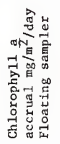 & 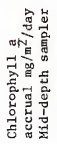 & 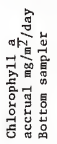 & 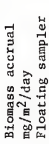 & 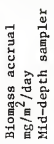 & 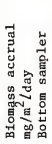 & 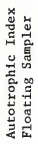 & 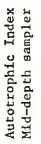 & 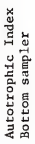 \\
\hline
\end{tabular}

Station 01

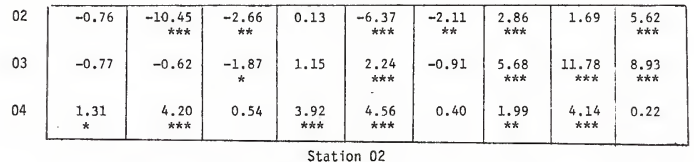

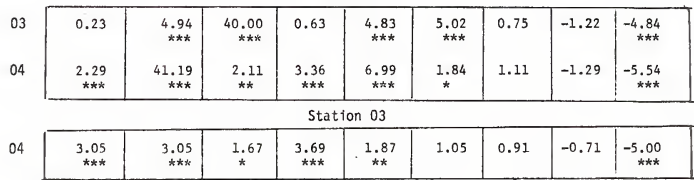

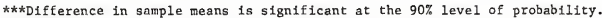
**Difference in sample means is significant at the $80 \%$ level of probability. *Difference in sample means is significant at the $70 \%$ level of probability.

Note: A positive $t$ value indicates an increase in the mean value at the downstream station; e.g., Chlorophyll a increased from Station 03 to Station 04 . A negative $t$ value indicates a decrease in mean value. $t$ values without an asterisk indicate differences in mean values that are not significant at the $70 \%$ level of probability. 
Table 15. Significance of differences between depths at each station in mean values for periphyton production variables using calculated $t$ values and appropriate degrees of freedom.

PERIPHYTON PRODUCTION VARIABLES

\begin{tabular}{|c|c|c|c|c|c|}
\hline 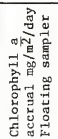 & 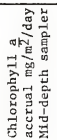 & 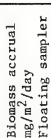 & 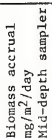 & 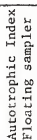 & 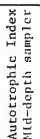 \\
\hline
\end{tabular}

Station 01

Mid-depth sampler

Bottom sampler

\begin{tabular}{|l|l|l|l|l|l|}
\hline-0.10 & & -0.68 & & -2.28 & \\
\hline$* * *$ & & \\
\hline-0.94 & $\begin{array}{c}-1.30 \\
*\end{array}$ & -0.96 & -0.62 & 0.16 & $\begin{array}{c}2.34 \\
* * *\end{array}$ \\
\hline
\end{tabular}

Station 02

Mid-depth sampler

Bottom sampler

\begin{tabular}{|c|c|c|c|c|c|}
\hline $\begin{array}{c}-2.48 \\
* *\end{array}$ & & $\begin{array}{c}-2.28 \\
* *\end{array}$ & & 1.26 & \\
\hline $\begin{array}{c}-2.54 \\
* *\end{array}$ & $\begin{array}{c}-3.00 \\
* * *\end{array}$ & $\begin{array}{c}-2.21 \\
* *\end{array}$ & 0.32 & $\begin{array}{c}5.22 \\
* * *\end{array}$ & $\begin{array}{c}2.38 \\
* * *\end{array}$ \\
\hline
\end{tabular}

Station 03

Mid-depth sampler

Bottom sampler

\begin{tabular}{|c|c|c|c|c|c|}
\hline 0.49 & & 0.34 & & -0.63 & \\
\hline $\begin{array}{r}-6.15 \\
* * *\end{array}$ & $-\begin{array}{c}-3.39 \\
* * *\end{array}$ & $\begin{array}{c}-8.35 \\
* * *\end{array}$ & $\begin{array}{c}-3.72 \\
* * *\end{array}$ & $\begin{array}{c}3.34 \\
* * *\end{array}$ & $\begin{array}{c}4.56 \\
* * *\end{array}$ \\
\hline
\end{tabular}

Station 04

Mid-depth sampler

Botton sampler

\begin{tabular}{|c|c|c|c|c|c|}
\hline-0.54 & & -1.91 & & -1.19 & \\
\hline-1.23 & -1.10 & $\begin{array}{r}-3.83 \\
\star \star \star\end{array}$ & $\begin{array}{r}-2.81 \\
\star \star \star \star\end{array}$ & $\begin{array}{c}-1.82 \\
\star \star *\end{array}$ & -1.71 \\
\hline
\end{tabular}

***Difference in sample means is significant at the $90 \%$ level of probability.

**Difference in sample means is significant at the $80 \%$ level of probability.

*Difference in sample means is significant at the $70 \%$ level of probability.

Note: A negative $t$ value indicates a decrease in the value with depth; e.g., Chlorophyll a decreased from the floating sampler at Station 02 to the mid-depth sampler at Station 02. A positive $t$ value indicates an increase in mean value. $t$ values without an asterisk indicate differences between mean values that are not significant at the $70 \%$ level of probability. 
Table 16. Rank (by estimated volume) and abundance of diatoms and non-diatom algal genera found on artificial substrates in the Sun River ( $\mathrm{R}=$ rare, $\mathrm{C}=$ common, $\mathrm{VC}=$ =very common, $\mathrm{A}=$ abundant, $\mathrm{VA}=\mathrm{very}$ abundant).

\begin{tabular}{|c|c|c|c|c|c|c|c|c|}
\hline \multirow{2}{*}{ Depth } & \multicolumn{2}{|l|}{ Station 01} & \multicolumn{2}{|c|}{ Station 02} & \multicolumn{2}{|l|}{ Station 03} & \multicolumn{2}{|l|}{ Station 04} \\
\hline & Rank & Abundance & Rank & ance & Rank & lance & Rank & ance \\
\hline Surface & $\begin{array}{l}\text { 1. Dlatoms } \\
\text { 2. Ulothrix } \\
\text { 3. Cosmarium } \\
\text { 4. Closterium } \\
\text { 5. Scenedesmus } \\
\text { 6. Stigeoclonium } \\
\text { 7. Oedogonium } \\
\text { 8. Pediastrum } \\
\text { 9. Oscillator a } \\
\text { 10. Dactylococcopsis }\end{array}$ & $\begin{array}{r}\mathrm{V} \Lambda \\
\mathrm{C} \\
\mathrm{C} \\
\mathrm{C} \\
\mathrm{C} \\
\mathrm{R} \\
\mathrm{R} \\
\mathrm{R} \\
\mathrm{R} \\
\mathrm{R}\end{array}$ & $\begin{array}{l}\text { 1. Dlatoms } \\
\text { 2. Ulothrix } \\
\text { 3. Cosmarium } \\
\text { 4. Phormidium } \\
\text { 5. Pediastrum } \\
\text { 6. Closterium }\end{array}$ & $\begin{array}{c}\mathrm{VA} \\
\mathrm{R} \\
\mathrm{R} \\
\mathrm{R} \\
\mathrm{R} \\
\mathrm{R}\end{array}$ & $\begin{array}{l}\text { 1. Diatoms } \\
\text { 2. Pedlastrum } \\
\text { 3. } \frac{\text { Cosmarium }}{\text { 4. }} \\
\text { 5losterium } \\
\text { 6. Scenedesmus } \\
\text { 7. } \text { Osormidium } \\
\text { 8. Ulothrix } \\
\text { 9. Oedogonium } \\
\text { 10. Dactylococcopsis } \\
\text { 11. Merismopedia }\end{array}$ & $\begin{array}{r}\mathrm{VA} \\
\mathrm{C} \\
\mathrm{VC} \\
\mathrm{C} \\
\mathrm{VC} \\
\mathrm{C} \\
\mathrm{C} \\
\mathrm{R} \\
\mathrm{R} \\
\mathrm{C} \\
\mathrm{R} \\
\end{array}$ & $\begin{array}{l}\text { 1. Dlatons } \\
\text { 2. } \text { Cosmarium } \\
\text { 3. Oscillatoria } \\
\text { 4. Closterium } \\
\text { 5. Dactylococcopsis } \\
\text { 6. Pediastrum } \\
\text { 7. Scenedcsmus } \\
\text { 8. Phormidium } \\
\text { 9. Anabaena } \\
\text { 10. Phacus }\end{array}$ & $\begin{array}{r}\text { VA } \\
\text { VC } \\
\text { VC } \\
\mathrm{C} \\
\mathrm{C} \\
\mathrm{R} \\
\mathrm{R} \\
\mathrm{R} \\
\mathrm{R} \\
\mathrm{R}\end{array}$ \\
\hline Mid-depth & $\begin{array}{l}\text { 1. Diatoms } \\
\text { 2. Closterium } \\
\text { 3. Pediastrum } \\
\text { 4. } \frac{\text { Cosmarium }}{\text { 5. Spirogyra }} \\
\text { 6. Oedogonium } \\
\text { 7. Scenedesmus } \\
\text { 8. Stigeoclonium } \\
\text { 9. Ulothrix } \\
\text { 10. Mougeotia } \\
\text { 11. Phormidium } \\
\text { 12. Gloeocystis } \\
\text { 13. Dactylococcopsis }\end{array}$ & $\begin{array}{l}\mathrm{VA} \\
\mathrm{VC} \\
\mathrm{C} \\
\mathrm{C} \\
\mathrm{R} \\
\mathrm{R} \\
\mathrm{C} \\
\mathrm{R} \\
\mathrm{R} \\
\mathrm{R} \\
\mathrm{R} \\
\mathrm{R} \\
\mathrm{R}\end{array}$ & $\begin{array}{l}\text { 1. Diatoms } \\
\text { 2. Cosmarium }\end{array}$ & $\begin{array}{l}\mathrm{C} \\
\mathrm{R}\end{array}$ & $\begin{array}{l}\text { 1. Diatoms } \\
\text { 2. Oscillatoria } \\
\text { 3. Closterium } \\
\text { 4. } \frac{\text { Cosmarium }}{\text { 5. Phormidium }} \\
\text { 6. } \text { Scenedesmus }\end{array}$ & $\begin{array}{l}\mathrm{A} \\
\mathrm{C} \\
\mathrm{R} \\
\mathrm{R} \\
\mathrm{R} \\
\mathrm{R}\end{array}$ & $\begin{array}{l}\text { 1. Diatoms } \\
\text { 2. Cosmarium } \\
\text { 3. Oscillatoria } \\
\text { 4. Closterium } \\
\text { 5. Scenedesmus }\end{array}$ & $\begin{array}{r}\mathrm{VA} \\
\mathrm{VC} \\
\mathrm{C} \\
\mathrm{R} \\
\mathrm{R}\end{array}$ \\
\hline Bottom & $\begin{array}{l}\text { 1. Diatoms } \\
\text { 2. Oedogonium } \\
\text { 3. Closterium } \\
\text { 4. Pediastrum } \\
\text { 5. } \frac{\text { Cosmarium }}{\text { 6. Spirogyra }} \\
\text { 7. Scenedesmus } \\
\text { 8. Microspora } \\
\text { 9. Stigeoclonium } \\
\text { 10. Phormidlum } \\
\text { 11. Dactylococcopsis }\end{array}$ & $\begin{array}{l}\mathrm{VA} \\
\mathrm{C} \\
\mathrm{C} \\
\mathrm{C} \\
\mathrm{C} \\
\mathrm{R} \\
\mathrm{C} \\
\mathrm{R} \\
\mathrm{R} \\
\mathrm{R} \\
\mathrm{R}\end{array}$ & $\begin{array}{l}\text { 1. Diatoms } \\
\text { 2. Oscillatoria }\end{array}$ & $\begin{array}{l}\mathrm{C} \\
\mathrm{R}\end{array}$ & $\begin{array}{l}\text { 1. Diatoms } \\
\text { 2. Oscillatoria } \\
\text { 3. Closterium } \\
\text { 4. Pediastrum } \\
\text { 5. Cosmarium } \\
\text { 6. Scenedesmis }\end{array}$ & $\begin{array}{r}\mathrm{vC} \\
\mathrm{C} \\
\mathrm{R} \\
\mathrm{R} \\
\mathrm{R} \\
\mathrm{R}\end{array}$ & $\begin{array}{l}\text { 1. Diatoms } \\
\text { 2. Oscillatoria } \\
\text { 3. Cosmarium } \\
\text { 4. Closterium }\end{array}$ & $\begin{array}{r}\mathrm{VA} \\
\mathrm{VC} \\
\mathrm{C} \\
\mathrm{R}\end{array}$ \\
\hline
\end{tabular}


Table 17. Diatom taxa identified from artificial substrates in the Sun River and corresponding percent relative abundance values by station and sampler depth ( $t=$ trace; found in scan but not during proportional count),

Taxon

Achnanthes deflexa Grun.

A. flexella (Kutz.) Grun.

A. lanceolata (Breb.) Grun.

A. Ianceolata var. dubia Grun.

A. Iinearis (W. Sm.) Grun.

A. 1inearis f. curta H.L. Sm.

A. microcephala (Kutz.) Grun.

A. minutissima Kutz.

Amphipleura pellucida Kutz.

Amphora ovalis var. affinis (Kutz,) V.H. ex DeT.

A. ovalis var. pediculus (Kutz.) V.H.

A. perpusilla (Grun.) Grun.

A. veneta (Kutz.) Hust.

Anomoeoneis vitrea (Grun.) Ross

Caloneis bacillum (Grun.) C1.

C. limosa (Kutz.) Patr.

C. ventricosa var. truncatula (Grun.) Meist. Cocconeis pediuclus Ehr.

C. placentula Ehr.

C. placentula var. euglypta (Ehr.) C1.

C. placentula var. 1ineata (Ehr.) V.H.

Cyclotella atomus hust.

C. meneghiniana Kutz.

c. striata (Kutz.) Grun.

Cymatopleura solea (Breb. \& Godey) $\mathrm{h} . \mathrm{Sm}$.

Cymbella affinis Kutz.

C. amphicephala Naeg.

c. cesatii Grun.

C. delicatula Kutz.

C. Iaevis Naeg.

C. Iunata W. Sm.

C. microcephala Grun.

C. minuta Hilse ex Rabh.

C. $\underline{\text { minuta }}$ var. silesiaca (Bleisch ex Rabh.) Reim.
Station 01

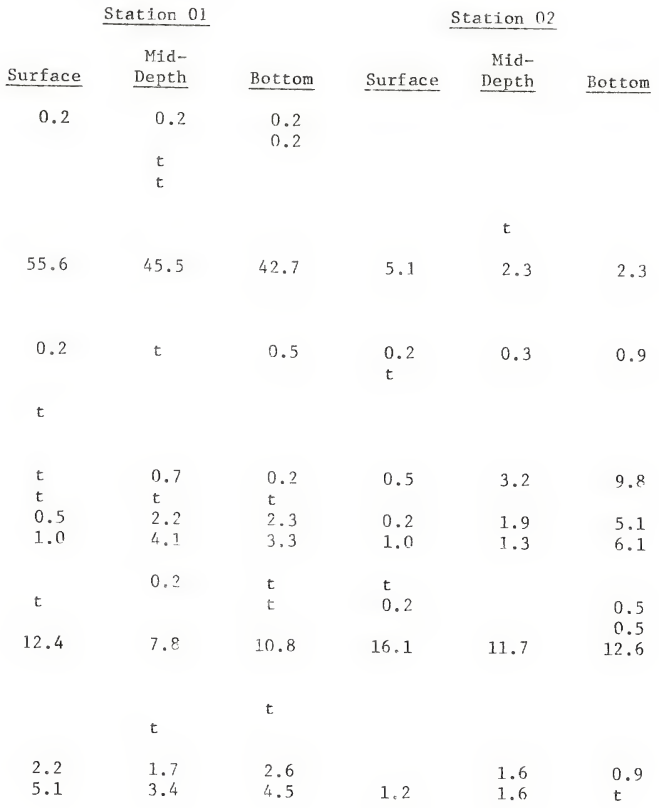


Station 01

\section{Taxon}

Cymbe1la muelleri Hust.

C. prostrata (Berkeley) $\mathrm{C} 1$.

C. Pusilla Grun.

C. sinuata Greg.

C. tumidula Grun.

$\bar{C}$. turgidula Grun.

Denticula tenuis var. crassula (Naeg. ex Kutz.)

W. \& G.S. West

Diatoma hiemale var. mesodon (Ehr.) Grun.

D. tenue Ag.

D. tenue var. elongatum Lyngb.

$\bar{D}$. vulgare Bory

Diploneis pseudovalis Hust.

Fragilaria brevistriata Grun.

F. construens var. venter (Ehr.) Grun.

F. Ieptostauron (Ehr.) Hust.

F. pinnata Ehr.

F. pinnata var. intercedens (Grun.) Hust.

F. vaucheriae (Kutz.) Peters

$\bar{F}$. vaucheriae var. continua A. Cl.

F. virescens Ralfs

Gomphonema angustatum (Kutz.) Rabh.

G. angustatum var. citera (Hohn \& Hellerm.) Patr.

G. bohemicum Reichelt et Fricke

G. dichotomun Kutz.

G. olivaceum (Lyngb.) Kutz.

G. parvulum (Kutz.)

$\vec{G}$. subclavatum (Grun.) Grun.

G. tenellum Kutz.

G. tergestinum (Grun.) Fricke

G. sp. I

Gyrosigma spencerii var. curvula (Grun.) Reim.

Hantzschia amphioxys (Ehr.) Grun.
Station 02

$\begin{array}{cccccc}\text { Surface } & \begin{array}{c}\text { Mid- } \\ \text { Depth }\end{array} & \text { Bottom } & \text { Surface } & \begin{array}{r}\text { Mid- } \\ \text { Depth }\end{array} \\ & 10.5 & 12.2 & \begin{array}{c}\mathrm{t} \\ \mathrm{t}\end{array} & 0.3 \\ 0.5 & \mathrm{t} & 0.7 & 0.2 & \\ & & & & 1.0\end{array}$

0.2

1.0

0.2

0.2

0.2

1.2

1.2

0.5

0.2

0.2

11.7

10.0

15.0

0.2

0.5

0.3

0.2

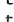

2.4

3.2

3.1

t

$t$

1.3

0.5

$t$

0.2

0.2

0.2

1.5

2.7

1.7

0.7

0.2

0.2

0.7

15.9

2.0

0.7

0.7

0.2

$\mathrm{t}$

2.4

1.0

t

0.5

1.9

0.3

0.3

33.7

1.3

2.8

4.2

0.5

3.7

0.5

0.5

0.5 
Taxon

Melosira varians Ag.

Navicula anglica var. subsalsa (Grun.) C1.

N. arenaria Donk

N. atomus (Kutz.) Grun.

N. capitata Ehr.

$\bar{N}$. capitata var. hungarica (Grun.) Ross

N. cincta (Ehr.) Ralfs

$\overline{\mathrm{N}}$. cincta var. rostrata Reim.

N. circumtexta Meist. ex Hust.

$\bar{N}$. cryptocephala var. veneta (Kutz.) Rabh.

$\overline{\mathrm{N}}$. cuspidata (Kutz.) Kutz.

$\overline{\mathrm{N}}$. gottlandica Grun.

$\overline{\mathrm{N}}$. gregaria Donk.

$\bar{N}$. heufleri Grun.

If $\overline{\mathrm{N}} \cdot$ heufleri var. 1eptocephala (Breb. \& Grun.) Patr.

N. Laevissima Kutz.

$\overline{\mathrm{N}}$. Ianceolata (Ag.) Kutz.

$\bar{N}$. menisculus var. upsaliensis

(Grun. in $\mathrm{Cl}$, \& Grun.) Grun.

N. notha Wallace

$\bar{N}$. pavillardii Hust.

N. peregrina (Ehr.) Kutz.

N. pupula Kutz.

N. pygmaea Kutz.

N. radiosa Kutz.

$\overline{\mathrm{N}}$. radiosa var. tenella (Breb. \& Kutz.) Grun.

$\overline{\mathrm{N}}$. rhynchocephala var. germanii (Wallace) Patr.

$\overline{\mathrm{N}}$. salinarum var. intermedia (Grun.) Cl.

$\overline{\mathrm{N}}$. symmetrica Patr.

$\bar{N}$. tripunctata (O.F. Mull.) Bory

$\overline{\mathrm{N}}$. viridula (Kutz.) Kutz.

N. viridula var. avenacea (Breb. \& Grun.) V.H.

$\overline{\mathrm{N}}$. viridula var. Tostellata (Kutz.) $\mathrm{Cl}$.

$\overline{\mathrm{N}}$. sp.

Nitzschia acicularis (Kutz.) W. SM.
Surface Mid-

Bottom

Surface

Mid-

Depth

Bottom

$t$

0.2

t

0.5

1.4

0.2

0.5

0.7

1.5

1. 3

0.5

0.2

0.3

t

0.5

0.2

t

2.7

4. 4

2.1

1.2

2.3

0.5

1.5

2. 9

1. 6

15.2

0.3

0.3

0.2

0.7

0.5
1.7

6.8

12.1

0.2

t

6.8

9.1

3.3

4.7

$0.2 \quad 0.2$


Taxon

Nitzschia acuta Hantz.

N. amphibia Grun.

$\overline{\mathrm{N}}$. angustata var. acuta Grun.

$\bar{N}$. apiculata (Gregory) Grun.

$\overline{\mathrm{N}}$. bergii A. C1.

$\bar{N}$. capitellata Hust.

$\bar{N}$. closterium (Ehr.) W. Sm.

$\overline{\mathrm{N}}$. denticula Grun.

$\overline{\mathrm{N}}$. dissipata (Kutz.) Grun.

$\overline{\mathrm{N}}$. elliptica Hust.

$\overline{\mathrm{N}}$. filiformis (W. Sm.) Hust.

$\overline{\mathrm{N}}$. fonticola Crun.

$\bar{N}$. frustulum Kutz.

$\overline{\mathrm{N}}$. frustulum var. perminuta Grun.

a $\overline{\mathrm{N}}$. frustulum var. perpusilla (Rabh.) Grun.

$\bar{N}$. frustulum var. subsalina Hust.

$\bar{N}$. goetzeana var. gracilior Hust.

$\overline{\mathrm{N}}$. gracilis Hantz.

$\bar{N}$. hantzschiana Rabh.

$\bar{N}$. hungarica Grun.

$\bar{N}$. kutzingiana Hilse

$\bar{N}$. 1inearis (Ag. ex W. Sm.) W. Sm.

$\overline{\mathrm{N}}$ microcephala Grun.

$\bar{N}$. palea (Kutz.) W. Sm.

$\bar{N}$. paleacea Grun.

$\overline{\mathrm{N}}$. recta Hantz.

$\bar{N}$. romana Grun.

$\overline{\mathrm{N}}$. sigma (Kutz.) W. Sm.

N. sigmoidea (Ehr.) W. Sm.

$\overline{\mathrm{N}}$. sinuata var. tabellaria V. H.

$\bar{N}$. subinflata Hust.

$\bar{N}$. sublinearis Hust.

$\bar{N}$. tryblione1la var. levidensis (W. Sm.) Grun.

\begin{tabular}{|c|c|c|c|c|c|}
\hline \multicolumn{2}{|c|}{ Station 01} & & \multicolumn{3}{|c|}{ Station 02} \\
\hline Surface & $\begin{array}{l}\text { Mid- } \\
\text { Depth }\end{array}$ & Bottom & Surface & $\begin{array}{l}\text { Mid- } \\
\text { Depth }\end{array}$ & Bottom \\
\hline
\end{tabular}

0.2

$t$

t 0.2

0.2

0.5

0.3

$t$

$t$

$t$

t

$0.5-1.0 \quad 0.9$

0.2

1.5

0.9
0.7

4.6

0.3

2.3

0.9

1.9

0.2

0.5

0.2

0.3

t

0.2

t

0.2

0.2

t

0.7

0.2

0.7

0.5

0.2

1.6

2.0

1. 5

t

t 
Table 17. Continued

Taxon

Nitzschia vermicularis (Kutz.) Hantz.

N. sp. I

$\bar{N}$. sp. II

Pleurosigma delicatulum $W$. Sm.

Rhoicosphenia curvata (Kutz.) Grun.

Surirella angustata Kutz.

S. ovalis Breb.

S. ovata Kutz.

S. ovata var. pinnata (W. Sm.)

S. sp.

Synedra acus Kutz.

S. amphicephala Kutz.

S. delicatissima W. Sm.

S. fasciculata var. truncata (Grev.) Patr.

S. filiformis Grun.

S. parasitica (W. Sm.) Hust.

S. rumpens Kutz.

S. ulna (Nitz.) Ehr.

S. ulna var. danica (Kutz.) V.H.

S. $\underline{\text { ulna }}$ var. ramesi (Herib.) Hust. $t$
0.2

$\mathrm{t}$

0.2

0.2
0.7

$t$

0.2
Station 01

Station 02

Surface $\begin{array}{r}\text { Mid- } \\ \text { Depth }\end{array}$

t

t

t

t

t

t

0.7

0.3 
Table 17. Continued

\section{Taxon}

Achnanthes deflexa Grun.

A. flexella (Kutz.) Grun.

A. 1anceolata (Breb.) Grun.

A. $\overline{\text { lanceolata }}$ var. dubia Grun.

A. Iinearis (W. Sm.) Grun.

A. Iinearis f. curta H.L. Sm.

A. microcephala (Kutz.) Grun.

$\bar{A}$. minutissima Kutz.

Amphipleura pellucida Kutz.

Amphora ovalis var. affinis (Kutz.) V.H. ex DeT.

A. ovalis var. pediculus (Kutz.) V.H.

A. perpusilla (Grun.) Grun.

A. veneta (Kutz.) Hust.

Anomoeoneis vitrea (Grun.) Ross

Caloneis bacillum (Grun.) C1.

C. Limosa (Kutz.) Patr.

$\bar{C}$. ventricosa var. truncatula (Grun.) Meist. Cocconeis pediculus Ehr.

C. placentula Ehr.

C. placentula var. euglypta (Ehr.) $\mathrm{Cl}$.

C. placentula var. 1ineata (Ehr.) V.H. Cyclotella atomus Hust.

C. meneghiniana Kutz.

C. Striata (Kutz.) Grun.

Cymatopleura solea (Breb. \& Godey) W. Sm.

Cymbella affinis Kutz.
C. amphicephala Naeg.
c. cesatii Grun.
C. delicatula Kutz.
C. laevis Naeg.
C. Iunata W. Sm.
c. microcephala Grun.

Station 03

\begin{tabular}{|c|c|c|c|c|c|}
\hline \multicolumn{3}{|c|}{ Station 03} & \multicolumn{3}{|c|}{ Station 04} \\
\hline Surface & $\begin{array}{r}\text { Mid- } \\
\text { Depth }\end{array}$ & Bottom & Surface & $\begin{array}{l}\text { Mid- } \\
\text { Depth }\end{array}$ & Bottom \\
\hline
\end{tabular}

$\mathrm{t}$
0.2
0.7
0.2

24.6

17.3

0.5

24.8

16.1

9.1

0.2

t

0.2

0.7

1.2

0.2

$\mathrm{t}$

0.2

t

$\mathrm{t}$

$\mathrm{t}$

$t$

0.5

t

1.7

0.2

0.2

0.2

0.5

$t$

0.2

$t$

$t$

I. 5

0.5

$t$

0.2

t

$t$

0.2

$\mathrm{t}$
0.5

t

0.5

7.3

6.0

3.2

9.0

3.1

3.6

0.2

t

3.8
4.6

2.4

1.2

2. 7 
Taxon

Cymbella minuta Hilse ex Rabh.

C. minuta var. silesiaca (B1eisch ex Rabh.) Reim.

c. muelleri Hust.

C. prostrata (Berkeley) C1.

$\overline{\mathrm{C}}$. pusilla Grun.

C. sinuata Greg.

C. tumidula Grun.

$\bar{C}$. turgidula Grun.

Denticula tenuis var. crassula (Naeg. ex Kutz.)

W. \& G.S. West

Diatoma hiemale var. mesodon (Ehr.) Grun.

D. tenue Ag.

$\bar{D}$. tenue var. elongatum Lyngb.

a $\bar{D}$. vulgare Bory

Diploneis pseudovalis Hust.

Fragilaria brevistrata Grun.

F. construens var. venter (Ehr.) Grun.

F. Ieptostauron (Ehr.) Hust.

$\overline{\mathrm{F}}$. pinnata Ehr.

$\bar{F}$. pinnata var. intercedens (Grun.) Hust.

$\bar{F}$. vaucheriae (Kutz.) Peters

F. vaucheriae var. continua A. C1.

$\overline{\mathrm{F}}$. virescens Ralfs

Gomphonema angustatum (Kutz.) Rabh.

G. angustatum var. citera (Hohn \& Hellerm.) Patr.

$\bar{G}$. bohemicum Reiche $\overline{1 t}$ et Fricke

G. dichotomum Kutz.

$\bar{G}$. olivaceum (Lyngb.) Kutz.

G. parvulum (Kutz.)

$\vec{G}$. subclavatum (Grun.) Grun

$\bar{G}$. tenellum Kutz.

$\underline{G}$. tergestinum (Grun.) Fricke

G. sp. I

\section{Mid-}

Surface Depth

\section{0}

6.8

t

1.9

0.5

0.5

Bottom

Mid-

Depth

Bot tom

Surface

1.7

$\mathrm{t}$

4. 1

1.2

0.2

3.8

1.7

0.2

0.2

$\mathrm{t}$

1.21 .2

0.2

3.3

2. 2

1. 0

t

4.4

2. 6

0.5

$\mathrm{t}$

0.2

3.3

3.4

$t$

0.2

0.2

$\mathrm{t}$

0.2

t

2. 8

1. 7

1.5

0.9

0.2

t

t

0.9

t

0.7

1.0

1.4

1.0

2.9

1.6

4. 1

3.4

0.2

0.5
0.2

$$
0.2
$$

2.4

2.6

0.7 $\mathrm{t}$

$\mathrm{t}$

0.5

1.7

.5

1.2

0.2

t. 5 
Table 17. Continued

Station 03

Taxon

Gyrosigma spencerii var. curvula (Grun.) Reim.

Hantzschia amphioxyx (Ehr.) Grun.

Melosira varians Ag.

Navicula anglica var. subsalsa (Grun.) C1.

N. arenaria Donk.

$\bar{N}$. atomus (Kutz.) Grun.

$\bar{N}$. capitata Ehr.

$\bar{N}$. capitata var. hungarica (Grun.) Ross

$\bar{N}$. cincta (Ehr.) Ralfs

$\overline{\mathrm{N}}$. cincta var. rostrata Reim.

$\bar{N}$. circumtexta Miest. ex Hust.

$\overline{\mathrm{N}}$. cryptocephala var. veneta (Kutz.) Rabh.

$\overline{\mathrm{N}}$. cuspidata (Kutz.) Kutz.

N. gottlandica Grun.

N. gregaria Donk.

$\overline{\mathrm{N}}$. heufleri Grun.

$\overline{\mathrm{N}}$. heufleri var. Ieptocephala (Breb. \& Grun.) Patr.

N. Laevissima Kutz.

$\overline{\mathrm{N}}$. Ianceolata (Ag.) Kutz.

N. menisculus var. upsaliensis

(Grun. in $\mathrm{C} 1$. \& Grun.) Grun.

N. notha Wallace

$\bar{N}$. pavillardii Hust.

$\overline{\mathrm{N}}$. peregrina (Ehr.) Kutz.

$\overline{\mathrm{N}}$. pupula Kutz.

$\bar{N}$. pygmaea Kutz.

$\bar{N}$. radiosa Kutz.

$\overline{\mathrm{N}}$. radiosa var. tenella (Breb. \& Kutz.) Grun.

$\overline{\mathrm{N}}$. rhynchocephala var. germanii (Wa1lace) Patr.

$\overline{\mathrm{N}}$. salinarum var. intermedia (Grun.) $\mathrm{C} 1$.

$\overline{\mathrm{N}}$. symmetrica Patr.

$\bar{N}$. tripunctata ( 0.F. Mu11.) Bory

N. viridula (Kutz.) Kutz.
MidSurface Depth $t$

t

$t$

t

2.6

$\mathrm{t}$

$t$

1.4

0.5

1.4

$\mathrm{t}$

0.20 .2

$0.2 \quad 0.2$

0.2

$\mathrm{t}$

$t$

11.5

10.1

5.5

2.2

2.3

3.4
Station 04

Mid-

Depth

Bottom

0.7

0.2

0.2

0.2

2.9

0.5

0.7

0.5

1. 2

0.2

0.2

$\mathrm{t}$

0.7

$t$

t

0.2

0.5

$t$

0.2

$t$

$t$

9.2

0.2

4.4

2.7

5.4

t

t

0.7

0.7

t

$t$

$t$

$\begin{array}{rrr}t & t & \\ 15.1 & 11.5 & 15.8 \\ 8.7 & 13.2 & 10.4 \\ 0.5 & 1.4 & 0.7 \\ 12.8 & 19.1 & 27.2\end{array}$


Station 03

Taxon

\begin{tabular}{|c|c|}
\hline Surface & $\begin{array}{l}\text { Mid- } \\
\text { Depth }\end{array}$ \\
\hline 0.7 & 2.6 \\
\hline$t$ & $t$ \\
\hline 1.4 & 0.5 \\
\hline $\mathrm{t}$ & 0.2 \\
\hline$t$ & $\mathrm{t}$ \\
\hline 0.2 & 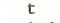 \\
\hline 0.2 & 1,2 \\
\hline
\end{tabular}

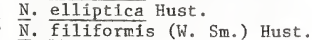

Navicula viridula var, avenacea (Breb. \& Grun.) V.H.

N. viridula var. rosteliata (Kutz.) $\mathrm{Cl}$

acicularis (Kutz.) $\mathrm{V}$. Sm.

ita Hantz.

N. angustata var. acuta Grun.

N. apiculata (Gregory) Grun.

N. bergii A. C1.

N. capitellata Hust.

closterium (Ehr.) W. Sm.

N. denticula Grun.

N. fonticola Grun.

$\bar{N}$. Erustulum Kutz.

N. frustulum var. perminuta Grun.

N. $\overline{\text { frustulum }}$ var. perpusilla (Rabh.) Grun.

$\bar{N}$. frustulum var. subsalina Hust.

$\bar{N}$. Eoetzeana var. gracilior Hust

N. gracilis Hantz.

$\overline{\mathrm{N}}$. hantzschiana Rabh.

$\bar{N}$. hungarica Grun.

N. kutzingiana Hilse

$\bar{N}$. Iinearis (Ag, ex W. Sm.) W. Sm.

$\overline{\mathrm{N}}$. microcephala Grun.

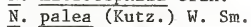

N. paleacea Grun.

N. recta Hantz.

$\bar{N}$. romana Grun.

N. $\overline{\text { sigma }}$ (Kutz.) W. Sm

N. Sigmoidea (Ehr.) W. Sm. $t$

0.2

4.5

0.2

Station 04

Mid-

Depth

Bottom

$\mathrm{t}$

$t$

0.20 .5

0.20 .2

0.5

0.5

0.2

0.2

$t$

5.8

4.9

0.7

3.3

$\mathrm{t}$

$\mathrm{t}$
3.9

$\begin{array}{lll}0.2 & \mathrm{t} & 0.2\end{array}$

0.2

0.2

0.2

0.5

0.2

(1)

1.9

0.5

0.2

0.7

0.9

0.9

1.0

0.7

$t$

0.2

$\mathrm{t}$

0.2

$0.5 t$

0.2

$t$

0.5

0.2

0.2

3.5

2.9

1.4

1. 7

0.2

1. 2

0.2

2.8

0.5

1.7

1.2

0.2

0.5

0.5

$t$ 
Table 17. Continued

Station 03

Taxon

Nitzschia sinuata var. tabellaria V. H.

N. subinflata Hust.

N. sublinearis Hust.

$\bar{N}$. tryblionella var. levidensis (W. Sm.) Grun.

$\bar{N}$. vermicularis (Kutz.) Hantz.

N. sp. I

N. sp. II

Pleurosigma delicatulum W. Sm.

Rhoicosphenia curvata (Kutz.) Grun.

Surirella angustata Kutz.

S. ovalis Breb.

S. ovata Kutz.

S. ovata var. pinnata (W. Sm.)

o s.

Synedra acus Kutz.

S. amphicephala Kutz.

S. delicatissima W. Sm.

S. fasciculata var. truncata (Grev.) Patr.

S. filiformis Grun.

S. Parasitica (W. Sm.) Hust.

S. rumpens Kutz.

S. ulna (Nitz.) Ehr.

S. ulna var. danica (Kutz.) V.H.

S. ulna var. ramesi (Herib.) Hust.

$0.2 \quad 0.7$
Station 04

Mid-

Depth Bottom

Surface Depth Bottom Surface Depth Bottom

$0.5 \quad t$

t $\quad 0.5$

0.2

t

0.5

$t$

0.5

$t$

$0.7 \quad 2.4$

0.2

0.2

0.2

$0.9 \quad 0.7$

$\begin{array}{ll}\mathrm{t} & \\ 0.7 & 1.0\end{array}$

t

0.2

$t$
0.5

$t$

t

0.5

$t$

0.2

$t$

$t$

0.2

t

$t$ 
Tuble 18. The structure of diatom associations on gloss ilites in the Sun River. (Diversity and equitabillty after Weber, 1973. )

\begin{tabular}{|c|c|c|c|c|c|c|}
\hline $\begin{array}{l}\text { Water } \\
\text { quil Lty } \\
\text { station }\end{array}$ & $\begin{array}{l}\text { Poisithon of } \\
\text { periphyton } \\
\text { sampler }\end{array}$ & $\begin{array}{l}\text { No, of indl- } \\
\text { vidual diatorn } \\
\text { celis counted }\end{array}$ & $\begin{array}{l}\text { Total } \\
\text { number } \\
\text { of taxa }\end{array}$ & $\begin{array}{l}\text { Number } \\
\text { of taxet } \\
\text { counted }\end{array}$ & $\begin{array}{l}\text { Distom } \\
\text { diversity } \\
\text { (d) }\end{array}$ & $\begin{array}{c}\text { Dititom } \\
\text { equitability } \\
\text { (e) }\end{array}$ \\
\hline 01 & $\begin{array}{l}\text { Surface } \\
\text { Mid-degth } \\
\text { Bottom }\end{array}$ & $\begin{array}{l}412 \\
411 \\
426\end{array}$ & $\begin{array}{l}46 \\
52 \\
55\end{array}$ & $\begin{array}{l}29 \\
38 \\
35\end{array}$ & $\begin{array}{l}2.63 \\
3.25 \\
3.29\end{array}$ & $\begin{array}{l}0.29 \\
0.37 \\
0.40\end{array}$ \\
\hline 02 & $\begin{array}{l}\text { Surface } \\
\text { Mid-depth } \\
\text { Bottom }\end{array}$ & $\begin{array}{l}409 \\
309 \\
214\end{array}$ & $\begin{array}{l}51 \\
37 \\
42\end{array}$ & $\begin{array}{l}40 \\
30 \\
36\end{array}$ & $\begin{array}{l}3.95 \\
3.52 \\
4.20\end{array}$ & $\begin{array}{l}0.58 \\
0.57 \\
0.75\end{array}$ \\
\hline 03 & $\begin{array}{l}\text { Surface } \\
\text { Mid-depth } \\
\text { Bottom }\end{array}$ & $\begin{array}{l}426 \\
416 \\
411\end{array}$ & $\begin{array}{l}72 \\
74 \\
73\end{array}$ & $\begin{array}{l}44 \\
56 \\
54\end{array}$ & $\begin{array}{l}4.17 \\
4.74 \\
3.91\end{array}$ & $\begin{array}{l}0.60 \\
0.71 \\
0.41\end{array}$ \\
\hline 04 & $\begin{array}{l}\text { Surfawe } \\
\text { Mid-deptir } \\
\text { Bottom }\end{array}$ & $\begin{array}{l}423 \\
419 \\
412\end{array}$ & $\begin{array}{l}57 \\
63 \\
60\end{array}$ & $\begin{array}{l}313 \\
42 \\
40\end{array}$ & $\begin{array}{l}3.94 \\
4.11 \\
3.73\end{array}$ & $\begin{array}{l}0.64 \\
0.60 \\
0.48\end{array}$ \\
\hline
\end{tabular}


Table 19. Numbers of macroinvertebrate organisms colonizing basket samplers in the lower Sun River.

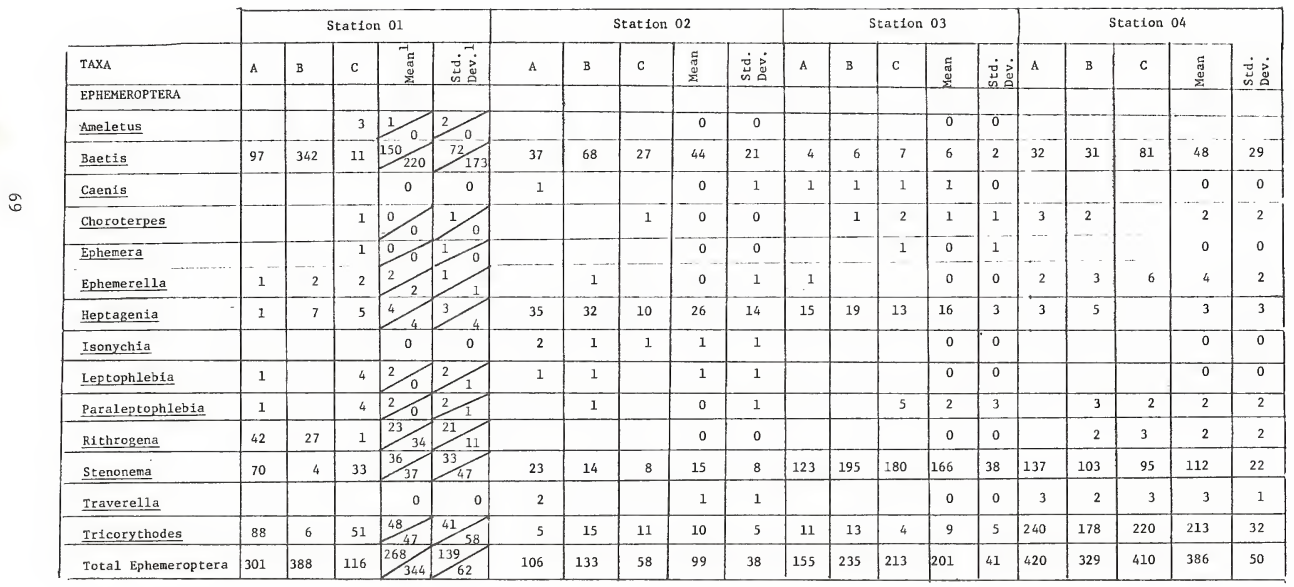


Table 19. Continued

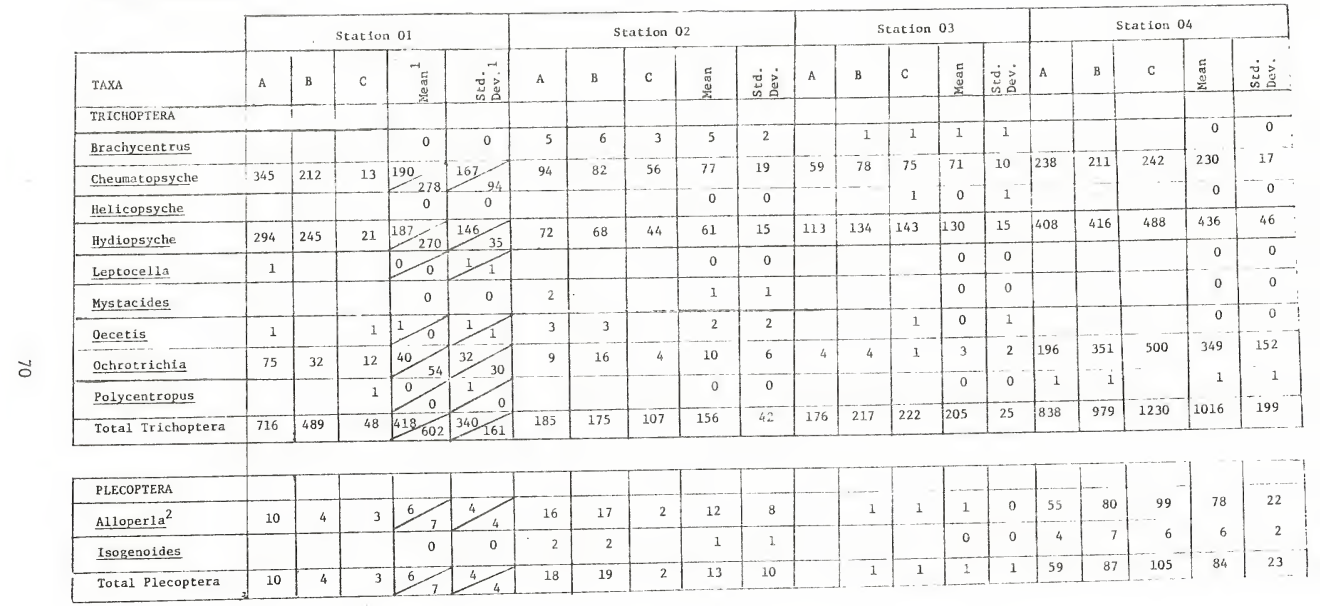


Table 19. Continued

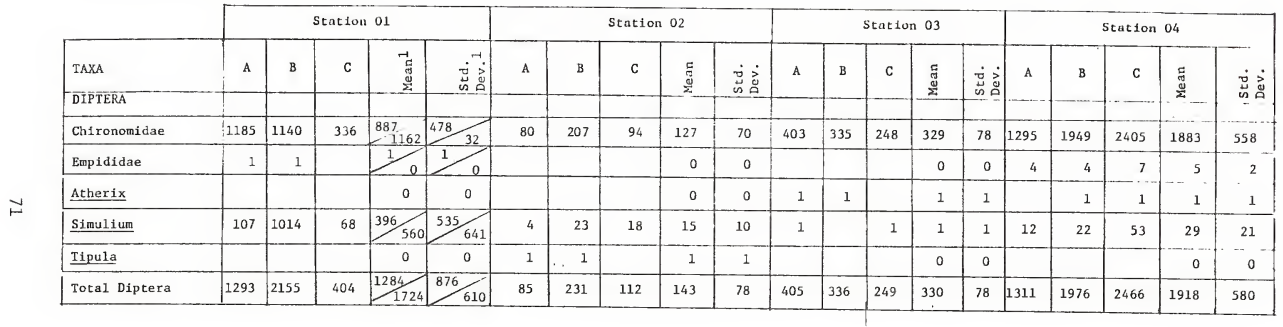

\begin{tabular}{|c|c|c|c|c|c|c|c|c|c|c|c|c|c|c|c|c|c|c|c|}
\hline COLEOPTERA & & & & & & & & & & & & & & & & & & & \\
\hline Cleptelmis & 1 & 1 & & & & & & 1 & 0 & 1 & & & 0 & 0 & & 1 & & 0 & 1 \\
\hline Helichus & & & & 0 & 0 & 4 & 1 & 3 & 3 & 2 & 2 & 1 & 1 & 1 & 2 & & & 1 & 1 \\
\hline Hygrotus & & & & 0 & 0 & 2 & 3 & 4 & 3 & 1 & 2 & 1 & 1 & 1 & 3 & 1 & 3 & 2 & \\
\hline Optioservus & 1 & & 1 & & & & 2 & 2 & 1 & 1 & & & 0 & 0 & & & 1 & 0 & 1 \\
\hline Stenelmis & 1 & & & & & & & & 0 & 0 & & & 0 & 0 & & & & 0 & 0 \\
\hline Total Coleoptera & 3 & 1 & 1 & & & 6 & 6 & 10 & 7 & 2 & 4 & 2 & 2 & 2 & 5 & 2 & 4 & 4 & 2 \\
\hline
\end{tabular}




\begin{tabular}{|c|c|c|c|c|c|c|c|c|c|c|c|c|c|c|c|c|c|c|c|c|}
\hline & \multicolumn{5}{|c|}{ Station 01} & \multicolumn{5}{|c|}{ Station 02} & \multicolumn{5}{|c|}{ Station 03} & \multicolumn{5}{|c|}{ Station 04} \\
\hline OTHER TAXA & A & 8 & $\mathrm{C}$ & 敢 & 岁 & A & B & $\mathrm{C}$ & 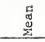 & 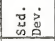 & $\mathbf{A}$ & B & c & 弯 & 苛 & A & B. & $\mathrm{c}$ & 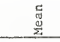 & 总家 \\
\hline ODON $A T A$ & & & & & & & & & & & & & & & 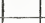 & & & & & \\
\hline Ishnura & & & & 0 & 0 & 1 & & & 0 & 1 & & & & 0 & 0 & & & & 0 & 0 \\
\hline Ophiogomphus & & & & 0 & 0 & 1. & 1 & 1 & 1 & 0 & & 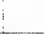 & & 0 & 0 & & & & 0 & 0 \\
\hline HEMIPTERA & & & & & & & & & & & & & & & & & & & & \\
\hline Trichocorixa & & & 4 & & & & & & 0 & 0 & & 2 & 2 & 1 & 1 & & & & 0 & 0 \\
\hline LEPIDOPTERA & & & & & & & & & & & & : & & & & & & & & \\
\hline Paragyractis & 1 & & 4 & & & & & & 0 & 0 & & & & 0 & 0 & & & & 0 & 0 \\
\hline AMPHIPODA & & & & & & & & & & & & & & & & & & & & \\
\hline HyaleIla & & & & 0 & 0 & & 1 & & 0 & 1 & & : & & 0 & 0 & & : & & 0 & 0 \\
\hline Hydracarina & 6 & 4 & 1 & & & & & 1 & 0 & 1 & 2 & 1 & & 1 & 1 & & 3 & 3 & 2 & 2 \\
\hline Collembola & & & & 0 & 0 & & & & 0 & 0 & & 1 & & 0 & 1 & & & & 0 & 0 \\
\hline Nemata & 6 & 8 & 3 & & & & 1 & 2 & 1 & $\lambda$ & 1 & 5 & 2 & 3 & 2 & 16 & 21 & 22 & 20 & 3 \\
\hline Total other Taxa & 13 & 16 & 8 & & & 2 & 3 & 4 & 3 & 1 & 3 & 9 & 4 & 5 & 3 & 16 & 24 & 25 & 22 & 5 \\
\hline $\begin{array}{l}\text { Total Organisms } \\
\text { Per Sampler }\end{array}$ & 2236 & 3053 & 580 & & & 402 & 567 & 293 & 421 & 138 & 739 & 802 & 691 & 744 & 56 & 2694 & 3397 & 4240 & 3429 & 796 \\
\hline $\begin{array}{l}\text { Number of Taxa } \\
\text { Per Sampler }\end{array}$ & 23 & 17 & 23 & & & 23 & 24 & 20 & 22 & 2 & 14 & 19 & 21 & 18 & 4 & 19 & 23 & 20 & 21 & 2 \\
\hline $\begin{array}{l}\text { Total 0rganisms } \\
\text { Per Station }\end{array}$ & & & & & & 1262 & & & & & 2232 & & & & & 10286. & & & & \\
\hline $\begin{array}{l}\text { Number of Taxa } \\
\text { Per Stat lun }\end{array}$ & & & & & & 31 & & & & & 25 & & & & & 25 & & & & \\
\hline
\end{tabular}

1 The upper values were calculated using replicates A, B and C; the lower valies sete calculated using A and B oniy. See text.

2 or inmature Hastaperla nymphs. 
Table 20. Significance of differences between stations in percent relative abundance (PRA) values for major macroinvertebrate taxa, using calculated $t$ values and appropriace degrees of freedom.

\begin{tabular}{|c|c|c|c|c|c|c|c|c|c|}
\hline \multicolumn{4}{|c|}{ EPHEMEROPTERA } & \multicolumn{3}{|c|}{ TRICHOPTERA } & \multirow[b]{2}{*}{ PLECOPTERA } & \multicolumn{2}{|c|}{ DIPTERA } \\
\hline 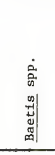 & 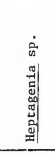 & 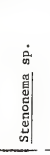 & 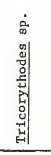 & 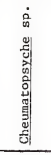 & 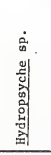 & 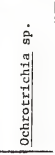 & & 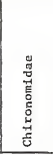 & 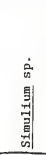 \\
\hline \multicolumn{10}{|c|}{ Station 01} \\
\hline 0.85 & $\begin{array}{r}3.76 \\
\star * \star \\
\end{array}$ & 1.21 & 0.34 & $\begin{array}{r}1.84 \\
* * \\
\end{array}$ & $\begin{array}{c}1.55 \\
*\end{array}$ & 0.01 & $\begin{array}{c}2.30 \\
\star \star\end{array}$ & $\begin{array}{c}-1.79 \\
\hbar *\end{array}$ & -1.05 \\
\hline-1.96 & $\begin{array}{r}9.79 \\
* * *\end{array}$ & $\begin{array}{r}5.35 \\
* * * \\
\end{array}$ & -0.42 & -0.43 & $\begin{array}{r}2.53 \\
x \neq *\end{array}$ & -1.60 & $\begin{array}{c}-1.54 \\
*\end{array}$ & $<0.01$ & $-1 \cdot 31$ \\
\hline-1.79 & -0.53 & 1.23 & 2.12 & -1.22 & 1.05 & 4.17 & 12.35 & $\begin{array}{r}1.68 \\
k \star \\
\end{array}$ & -1.26 \\
\hline \multicolumn{10}{|c|}{ Station 02} \\
\hline $\begin{array}{r}-10.00 \\
* * *\end{array}$ & $\begin{array}{c}-2.48 \\
* *\end{array}$ & $\begin{array}{r}6.08 \\
* * \star\end{array}$ & $\begin{array}{c}-1.65 \\
* \star \\
\end{array}$ & $\begin{array}{r}-3.49 \\
* * * \\
\end{array}$ & 1.10 & $\begin{array}{r}-3.98 \\
* * *\end{array}$ & $\underset{\substack{-2.52 \\
* \star}}{ }$ & $\begin{array}{l}1.96 \\
* k\end{array}$ & $\begin{array}{c}-2.44 \\
* \star\end{array}$ \\
\hline $\begin{array}{r}9.04 \\
\star * *\end{array}$ & $\begin{array}{r}-3.80 \\
* * *\end{array}$ & -0.12 & $\begin{array}{r}2.68 \\
\star \star \star\end{array}$ & $\begin{array}{c}-4.34 \\
* \pi\end{array}$ & -0.97 & $\begin{array}{r}5.67 \\
\star \star \star *\end{array}$ & -0.30 & $\begin{array}{l}4.38 \\
* \pi \hbar\end{array}$ & $\begin{array}{c}-1.95 \\
* \star\end{array}$ \\
\hline \multicolumn{10}{|c|}{ Station 03} \\
\hline $\begin{array}{c}1.77 \\
* *\end{array}$ & $\begin{array}{r}-13.22 \\
* * *\end{array}$ & $\begin{array}{r}-6.24 \\
\star * *\end{array}$ & $\begin{array}{r}3.98 \\
k * *\end{array}$ & $\underset{* k}{-1.94}$ & $\begin{array}{r}-2.32 \\
* * *\end{array}$ & $\begin{array}{l}7.28 \\
\star * *\end{array}$ & $\begin{array}{r}21.93 \\
* * *\end{array}$ & $\begin{array}{c}1.67 \\
* *\end{array}$ & $\underset{* \star}{2.82}$ \\
\hline
\end{tabular}

$* *$ Difference in sample means is significant at the $90 \%$ level of probability. **Difference in sample means is slgnificant at the $80 \%$ level of probability.

$*$ Difference in sample means is significant at the $70 \%$ level of probability.

Note: A positive $t$ value indicates an increase in the mean PRA at the downstream station; e.g., Heptagenia PRA increased from station 01 to station 02 . A negative $t$ value indicates a decrease in mean PRA. $t$ values without an asterisk indicate differences in mean PRA that are not significant at the $70 \%$ level of probability. 
Table 21. Significance of differences between stations in mean values for macroinvertebrate community structure variables, using calculated $t$ values and appropriate degrees of freedon.

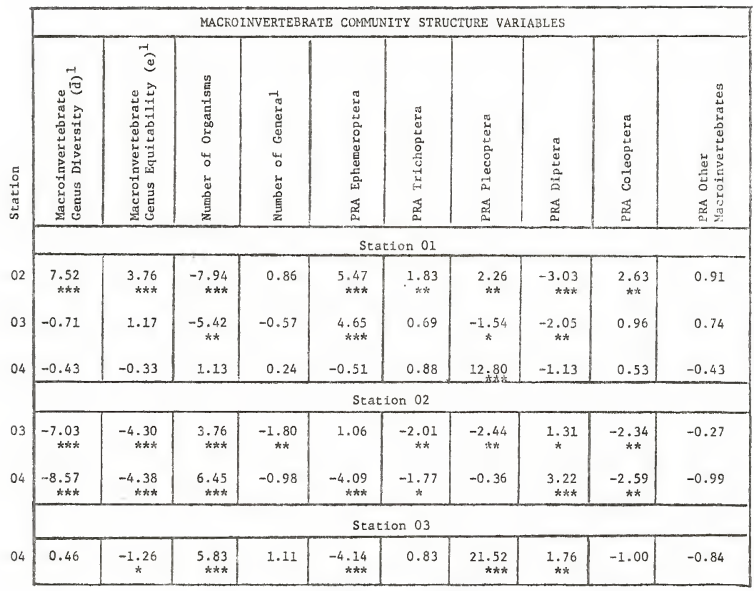

\footnotetext{
***Difference in sample neans is signiflcant at the $90 \%$ level of probability. * Difference in sample means is significant at the $80 \%$ level of probability. *Difference in sample means is significant at the $70 \%$ level of probability.

Note: A positive $t$ value indicates an increase in the mean value at the downstream station; e.8., genus diversity increased from station 01 to station 02 . A negative $t$ value indicates a decrease in mean value. $t$ values without an asterisk indicate differences in mean values that are not significant at the $70 \%$ level of probability.

lMidges were identifled only to family (Chironomidae) and counted as one genus.
} 

